\title{
Aberrant Calcium/Calmodulin-Dependent Protein Kinase II (CaMKII) Activity Is Associated with Abnormal Dendritic Spine Morphology in the ATRX Mutant Mouse Brain
}

\author{
Norifumi Shioda, ${ }^{1}$ Hideyuki Beppu, ${ }^{2}$ Takaichi Fukuda, ${ }^{3}$ En Li, ${ }^{4}$ Isao Kitajima, ${ }^{2}$ and Kohji Fukunaga ${ }^{1}$ \\ ${ }^{1}$ Department of Pharmacology, Graduate School of Pharmaceutical Sciences, Tohoku University, Sendai 980-8578, Japan, ${ }^{2}$ Department of Clinical \\ and Molecular Pathology, Faculty of Medicine, University of Toyama, Toyama 930-0194, Japan, ${ }^{3}$ Department of Anatomy and Neurobiology, \\ Graduate School of Medical Sciences, Kyushu University, Fukuoka 812-8582, Japan, and ${ }^{4}$ Novartis Institutes for BioMedical Research, Inc., \\ Cambridge, Massachusetts 02139
}

In humans, mutations in the gene encoding ATRX, a chromatin remodeling protein of the sucrose-nonfermenting 2 family, cause several mental retardation disorders, including $\alpha$-thalassemia X-linked mental retardation syndrome. We generated ATRX mutant mice lacking exon $2\left(A T R X^{\triangle E 2}\right.$ mice), a mutation that mimics exon 2 mutations seen in human patients and associated with milder forms of retardation. $A T R X^{\triangle E 2}$ mice exhibited abnormal dendritic spine formation in the medial prefrontal cortex (mPFC). Consistent with other mouse models of mental retardation, $A T R X^{\triangle E 2}$ mice exhibited longer and thinner dendritic spines compared with wild-type mice without changes in spine number. Interestingly, aberrant increased calcium/calmodulin-dependent protein kinase II (CaMKII) activity was observed in the MPFC of $A T R X^{\triangle E 2}$ mice. Increased CaMKII autophosphorylation and activity were associated with increased phosphorylation of the Rac1-guanine nucleotide exchange factors (GEFs) T-cell lymphoma invasion and metastasis 1 (Tiam1) and kalirin-7, known substrates of CaMKII. We confirmed increased phosphorylation of p21-activated kinases (PAKs) in mPFC extracts. Furthermore, reduced protein expression and activity of protein phosphatase 1 (PP1) was evident in the mPFC of $A T R X^{\triangle E 2}$ mice. In cultured cortical neurons, PP1 inhibition by okadaic acid increased CaMKII-dependent Tiam1 and kalirin-7 phosphorylation. Together, our data strongly suggest that aberrant CaMKII activation likely mediates abnormal spine formation in the mPFC. Such morphological changes plus elevated Racl-GEF/PAK signaling seen in $A T R X^{\Delta E 2}$ mice may contribute to mental retardation syndromes seen in human patients.

\section{Introduction}

Typical $\alpha$-thalassemia X-linked mental retardation (ATR-X; online Mendelian inheritance in man 301040) syndrome is a well known X-linked condition marked by cognitive deficits. ATR-X syndrome is characterized by various clinical manifestations including severe mental retardation, facial dysmorphism, genital abnormalities, and epileptic seizures (Wilkie et al., 1991; Gibbons et al., 1995a). The ATRX gene encodes a protein containing two signature motifs: a plant homeodomain-type zinc finger domain and a DNA-dependent ATPase domain of the SNF-2 (sucrosenonfermenting 2) family, the latter of which is a putative ATPdependent chromatin-remodeling protein (Gibbons et al., 1995b,

\footnotetext{
Received Sept. 14, 2010; revised 0ct. 21, 2010; accepted 0ct. 21, 2010.

This work was supported in part by Grants-in-Aid for Scientific Research from the Ministry of Education, Science, Sports and Culture of Japan (22390109 and 22659012 to K.F.) and the Smoking Research Foundation (to K.F.). We thank Professor Toshio Kosaka in Department of Anatomy and Neurobiology, Graduate School of Medical Sciences, Kyushu University, for helpful advice in spine morphological analysis.

Correspondence should be addressed to Dr. Kohji Fukunaga, Department of Pharmacology, Graduate School of Pharmaceutical Sciences, Tohoku University, Aramaki-Aoba Aoba-ku, Sendai 980-8578, Japan. E-mail: fukunaga@mail.pharm.tohoku.ac.jp.

T. Fukuda's present address: Department of Anatomy, Graduate School of Medical Sciences, Kumamoto University, Kumamoto 860-8556, Japan.

DOI:10.1523/JNEUROSCI.4816-10.2011

Copyright $\odot 2011$ the authors $\quad 0270-6474 / 11 / 310346-13 \$ 15.00 / 0$
}

Picketts et al., 1996). Several ATRX mutations have been identified in patients with ATR-X syndrome (Picketts et al., 1996; Gibbons et al., 1997; Fichera et al., 1998; Villard et al., 1999). Mutations in ATRX are also found in Juberg-Marsidi syndrome (Villard et al., 1996a), in Carpenter-Waziri syndrome (Abidi et al., 1999), in mental retardation with spastic paraplegia (Lossi et al., 1999), and in ATR-X patients without $\alpha$-thalassemia (Villard et al., 1996b, 1996c). These findings clearly indicate that multiple ATRX gene mutations are associated with a wide spectrum of clinical disorders. Relatively mild mental retardation observed in ATR-X patients with an Arg37Stop (R37X) mutation in exon 2 is accompanied by reduced expression of ATRX protein in lymphoblastoid cells (Howard et al., 2004). Three males with ChudleyLowry syndrome (Chudley et al., 1988) have been found to exhibit the ATRX R37X mutation (Abidi et al., 2005). We recently generated $A T R X$ mutant mice lacking exon $2\left(A T R X^{\Delta E 2}\right.$ mice) that showed mild learning impairments (Nogami et al., 2010). The particular mutation carried by these mice corresponds that seen in a variant of human ATR-X syndrome, which includes Chudley-Lowry syndrome.

Mental retardation has been consistently associated with changes in dendrite arborization and dendritic spine morphology (Kaufmann and Moser, 2000). More than three decades ago, Purpura 
(1974) reported abnormal long, thin spines resembling immature filopodia in the motor cortex of mentally retarded children, suggesting that aberrant dendritic arborization and spine morphology is associated with that condition. $\mathrm{Ca}^{2+} /$ calmodulin-dependent protein kinase II (CaMKII) is a serine/threonine kinase regulated by intracellular calcium and significantly by activity of the NMDA receptor in spine postsynaptic densities. In dendritic spines, CaMKII is associated with NMDA receptor subunits NR1 and NR2B (Merrill et al., 2005) and with other cytoskeletal elements, such as densin-180 and $\alpha$-actinin-2 in the postsynaptic density (Robison et al., 2005). CaMKII $\beta$ subunits also directly bind to F-actin (Shen et al., 1998), thereby modulating actin dynamics in cultured hippocampal neurons (Fink et al., 2003) and rat slice cultures (Okamoto et al., 2004). We also have provided strong evidence that CaMKII contributes to structural plasticity and spine formation in hippocampal neurons (Jourdain et al., 2003).

Here, we show abnormal elevation of CaMKII activity with concomitant remarkable elongation and thinning of spine structure in the medial prefrontal cortex (mPFC) of $A T R X^{\Delta E 2}$ mice. Moreover, we demonstrate that dysregulation of phosphorylation of Rac1-guanine nucleotide exchange factors (GEFs), such as T-cell lymphoma invasion and metastasis 1 (Tiam1) and kalirin-7 by abnormal CaMKII activity in ATRX mutant mice is closely associated with abnormal spine formation.

\section{Materials and Methods}

Animals. Generation of homozygous $A T R X^{\Delta E 2}$ mice has been described by Nogami et al. (2010). ATRX $X^{\Delta E 2}$ mice exhibit normal phenotypes with regard to survival and fertility. Adult 12-week-old male mice were used in all experiments. Mice were housed under climatecontrolled conditions with a $12 \mathrm{~h}$ light/dark cycle, and were provided standard food and water ad libitum. The experiments were approved by Institutional Animal Care and Use Committee at Tohoku University (permission No. 21-Pharm-Animal-1).

Behavioral tests. Y-maze and novel object recognition tests were performed as described previously (Han et al., 2008). The Y-maze apparatus, used to measure spontaneous alternation behavior, consisted of three identical black Plexiglas arms $(1 \times$ width $\times$ height, $50 \times 16 \times 32 \mathrm{~cm})$. Mice were placed at the end of one fixed arm and allowed to move freely through the maze during an $8 \mathrm{~min}$ session. The sequence of arm entries was recorded, and three consecutive choices were defined as one succeeded alternation. The percentage of alternations was calculated as (actual alternations/maximum alternations) $\times 100$. The total number of arms entered during the session was also determined. The novel object recognition test evaluates a rodent's ability to discriminate between familiar and novel objects. Exploratory behavior in the presence of a novel object requires memory-related processes. For this test, during acquisition phases two objects of the same material were placed symmetrically positioned from the center of the chamber $(35 \times 25 \times 35 \mathrm{~cm})$ for $10 \mathrm{~min}$. At 1 or $24 \mathrm{~h}$ after the last training, one object was replaced by a novel one and exploratory behavior was again analyzed during a 5 min period. Exploration of an object was defined as rearing on the object, sniffing it at a distance of $<1 \mathrm{~cm}$, and/or touching it with the nose. Successful recognition of a previously explored object is reflected by preferential exploration of the novel object. Discrimination of spatial novelty was assessed by comparing the difference in time of exploration of the novel and familiar object and the total time spent exploring both objects, a value that made it possible to adjust for differences in total exploration time. The Barnes maze was designed to test spatial learning and memory in rodents (Patil et al., 2009). It consists of a circular platform $(92 \mathrm{~cm}$ in diameter) with 20 holes (hole diameter: $5 \mathrm{~cm}$ ) along the perimeter. At the beginning of each trial, the mouse is placed in the middle of the maze in a cylindrical start chamber $(7.5 \mathrm{~cm})$. After $10 \mathrm{~s}$, the chamber is lifted and the mouse is free to explore the maze. The test ends when the mouse enters the goal tunnel or after $3 \mathrm{~min}$ have elapsed. Immediately after the mouse enters the tunnel, the mouse is allowed to stay in the tunnel for 1 min. Mice were trained for two trials per day for $4 \mathrm{~d}$. The following parameters were recorded: errors and search time required to escape into the tunnel. Errors were defined as nose pokes and head deflections over any hole that did not lead to a tunnel.

Contextual fear-conditioning test was performed as described previously (Nogami et al., 2010). Briefly, in the conditioning session, mice were placed in the conditioning chamber and allowed to explore for $120 \mathrm{~s}$. An electric footshock $(0.5 \mathrm{~mA}, 100 \mathrm{~V}, 2 \mathrm{~s})$ was then delivered, and after $30 \mathrm{~s}$ mice were returned to the home cage. Contextual fear memory tests were run by placing the mice back in the conditioning chamber for $360 \mathrm{~s}$ at $1 \mathrm{~d}, 3 \mathrm{~d}$ (recent memory), or $17 \mathrm{~d}$ (remote memory) after the conditioning session. Freezing was defined as immobility of animals lasting $>0.5 \mathrm{~s}$.

Measurement of locomotor activity during a $24 \mathrm{~h}$ period was performed as previously described (Shioda et al., 2010). Mice were housed individually in standard plastic cages and positioned in an automated open-field activity monitor using digital counters with an infrared sensor (DAS system, Neuroscience) in an isolated room under dim light between 8:30 A.M. and 8:30 P.M. Elevated plus maze test designed to assess the fear response was performed as described previously (Pellow et al., 1985). The apparatus consisted of a central $6 \times 6 \mathrm{~cm}$ platform and four arms radiating from the platform in the shape of a plus. The maze floor consisted of a central platform $(6 \times 6 \mathrm{~cm})$, two open arms $(30 \mathrm{~cm}$ in length, $6 \mathrm{~cm}$ in width), and two enclosed arms (30 cm in length, $6 \mathrm{~cm}$ in width, $15 \mathrm{~cm}$ high with nontransparent side and end walls). The maze floor was elevated to $70 \mathrm{~cm}$ above floor level. At the beginning of the 5 min test session, mice were placed in the center facing one enclosed arm. The following parameters were scored: (1) the number of total, open, and closed arm entries; and (2) time spent in different parts of the maze (open and closed arms, and central platform).

The light/dark transfer test was performed as described previously (Crawley and Goodwin, 1981). The white compartment was brightly illuminated with a light source, while the dark compartment was covered by a black top. Compartments were connected by a small opening $(5 \times 5 \mathrm{~cm}$ wide $)$ located in the center of the partition at floor level. Animals were individually placed in the dark compartment facing away from the opening and allowed to freely explore the apparatus for $10 \mathrm{~min}$. The following behaviors were scored: (1) number of shuttle crossings between the two compartments (number of entries in light compartment); (2) time spent in the light compartment; and (3) latency to the first entry into the light compartment.

Tissue slice preparation. For immunohistochemical and spine morphological studies, mice were anesthetized with pentobarbital and perfused via the ascending aorta with PBS, $\mathrm{pH} 7.4$, until the outflow became clear, followed by $0.1 \mathrm{M}$ phosphate buffer, $\mathrm{pH} 7.4$, containing $4 \%$ paraformaldehyde (PFA). The brain was removed, postfixed in the same solution at $4^{\circ} \mathrm{C}$, and then sliced using a vibratome (Dosaka EM). Coronal sections were prepared for immunohistochemistry, and sagittal sections were stained with hematoxylin and eosin.

Spine morphological studies using Lucifer yellow labeling in fixed slices. Intracellular Lucifer yellow (LY) labeling methods were performed as described previously (Murakawa and Kosaka, 2001). After LY injections into a large number of pyramidal neurons in the mPFC and hippocampal CA1 region, sections were fixed in the $0.1 \mathrm{~m}$ phosphate buffer, $\mathrm{pH} 7.4$, containing 4\% PFA for $5 \mathrm{~d}$; washed several times with PBS; incubated $1 \mathrm{~h}$ in PBS containing with $1 \%$ BSA, $0.3 \%$ Triton $\mathrm{X}-100$, and $0.1 \% \mathrm{NaN}_{3}$ (blocking solution); and reacted with a rabbit anti-LY polyclonal antibody (1:5000, Invitrogen) in blocking solution at $20^{\circ} \mathrm{C}$ for $5 \mathrm{~d}$. After washing, sections were incubated for $3 \mathrm{~h}$ with Alexa 488-labeled antirabbit IgG (1:500, Invitrogen). After several washes in PBS, sections were mounted on slides with Vectashield (Vector Laboratories). Immunofluorescent images were analyzed using a confocal laser scanning microscope (TCS, Leica/Olympus).

Immunohistochemical studies. Immunohistochemical studies were performed as previously described (Shioda et al., 2010a). Briefly, 50- $\mu \mathrm{m}-$ thick brain sections were incubated for $30 \mathrm{~min}$ in PBS containing $0.01 \%$ Triton $\mathrm{X}-100$, in blocking solution for $1 \mathrm{~h}$, and with various primary antibodies in blocking solution at $20^{\circ} \mathrm{C}$ for $5 \mathrm{~d}$. Antibodies included mouse monoclonal antibodies against microtubule-associated protein-2 (MAP-2) (1:1000, Millipore); neuronal nuclear antigen (NeuN) (1:1000, 
Millipore); glial fibrillary acidic protein (GFAP) (1:1000, Sigma-Aldrich); and rabbit polyclonal antibody against ATRX (H-300, 1:1000, Santa Cruz Biotechnology). After thorough washes in PBS, sections were incubated with secondary antibodies in blocking solution at $20^{\circ} \mathrm{C}$ for $1 \mathrm{~d}$. Antibodies included Alexa 594-labeled anti-mouse IgG and Alexa 448-labeled anti-rabbit IgG (1:500, Invitrogen). For nuclear staining with propidium iodide (PI), $50-\mu \mathrm{m}$-thick sections were incubated for $30 \mathrm{~min}$ in PBS containing $0.01 \%$ Triton X-100, for $1 \mathrm{~h}$ in blocking solution, and for $5 \mathrm{~d}$ with rabbit polyclonal antibody against ATRX (1:1000, Santa Cruz Biotechnology) in blocking solution at $20^{\circ} \mathrm{C}$. After thorough washing with PBS, sections were incubated for $1 \mathrm{~d}$ with Alexa 448-labeled anti-rabbit IgG (1:500, Invitrogen). After several PBS washes, sections were incubated with PI (1:200 in PBS, Invitrogen) for $10 \mathrm{~min}$.

Cell counting and spine morphological analysis. Cells staining positive for ATRX, NeuN, or GFAP in the infralimbic (IL) and prelimbic (PrL) regions of $\mathrm{mPFC}$ were counted in 16 random sampling boxes measuring $50 \times 50 \times 30 \mu \mathrm{m}$ (four sections per mouse; $n=3$ mice; $50 \mu \mathrm{m}$ apart). Spine morphological analyses were undertaken in layer II/III in IL and PrL regions of mPFC and in hippocampal CA1 regions from 8 to 11 neurons per mouse (from 17 to 20 oblique dendritic arbors of apical and basal dendritic arbors per mouse; $n=3$ mice). Spine length was calculated as the radial distance from the tip of spine head to the dendritic shaft. Spine head diameters were measured along an axis perpendicular to the spine neck, approximately in the middle of the spine head. For most spines, this diameter corresponded to the maximum dimension of the spine head. In cases where the spine head showed irregular morphology, or if the spine head maximum diameter was not perpendicular to the neck, we measured maximum head diameter. Spines were categorized according to Irwin et al. (2002), along an immature- to matureappearing spine continuum. For branching analysis, the complexity of basal dendrite branching was estimated by counting the number of branches on each dendrite. Data were expressed as means of the number of branches per dendrite. Measurements were done using ImageJ (National Institutes of Health freeware). The position of IL and PrL regions in the $\mathrm{mPFC}$ and hippocampal CA1 regions was identified using the criteria of Paxinos and Franklin (2001).

Immunoprecipitation and immunoblotting analysis. Immunoprecipitation and immunoblotting analysis was performed as previously described (Shioda et al., 2010a). Mouse brains were immediately removed and perfused in ice-cold buffer for $3 \mathrm{~min}(0.32 \mathrm{~m}$ sucrose, $20 \mathrm{~mm}$ Tris$\mathrm{HCl}, \mathrm{pH}$ 7.4). mPFCs were dissected and then homogenized in $200 \mu \mathrm{l}$ of buffer containing $50 \mathrm{~mm}$ Tris- $\mathrm{HCl}, \mathrm{pH} 7.4,0.5 \%$ Triton X-100, $0.5 \mathrm{M}$ $\mathrm{NaCl}, 4$ mм EDTA, 4 mм EGTA, 1 mм Na $\mathrm{VO}_{4}, 50$ mм NaF, 1 mм DTT, $2 \mu \mathrm{g} / \mathrm{ml}$ pepstatin A, $1 \mu \mathrm{g} / \mathrm{ml}$ leupeptin, and $100 \mathrm{~nm}$ calyculin $\mathrm{A}$, and then treated with Laemmli's sample solution and boiled for $3 \mathrm{~min}$. Antibodies included rabbit polyclonal antibodies against $p$-CaMKII $(\alpha$-Thr286/ $\beta$ Thr287) (1:5000) (Fukunaga et al., 1988); CaMKII (1:5000) (Fukunaga et al., 1988); synapsin I (1:1000) (Fukunaga et al., 1992); protein phosphatase 1 (PP1) (1:1000, the catalytic subunit of PP1 $\gamma$-1 and -2) (Fukunaga et al., 2000); PP2A catalytic subunit (1:1000) (Fukunaga et al., 2000); calcineurin (1:1000) (Shioda et al., 2006); p-CaMKI (Thr177), CaMKI (Han et al., 2009); p-CaMKIV (Thr196), CaMKIV (Kasahara et al., 1999), NR1, kalirin, p21-activated kinase 3 (PAK3), spinophilin, glutamate receptor 1 (GluR1), $p$-Ser/Thr, $p$-protein kinase $\mathrm{C} \alpha(\mathrm{PKC} \alpha)$ (Ser657), $\operatorname{PKC} \alpha$ (all at 1:1000, Millipore); Tiam1 (1:1000, Calbiochem); ATRX (H-300, 1:500, Santa Cruz Biotechnology); and p-PAK1 (Thr423), p-PAK2 (Thr402), p-PAK3 (Thr421), PAK1, PAK2, myosin II regulatory light chain (MLC), $p$-MLC (Ser19), extracellular signal-regulated kinase (ERK), p-ERK (Thr202/Tyr204) (all at 1:1000, Cell Signaling Technology). Mouse monoclonal antibodies used included $\beta$-tubulin (1:10000, Sigma-Aldrich); postsynaptic density-95 (PSD95) (1:1000, Affinity Bioreagents); MAP-2 (1:1000, Millipore); and GFAP (1:1000, Sigma-Aldrich).

CaMKII and protein phosphatase activity assays. Briefly, frozen mPFC samples were homogenized with a handheld homogenizer in $200 \mu \mathrm{l}$ of homogenizing buffer containing $0.5 \%$ Triton X-100, $50 \mathrm{~mm}$ Tris- $\mathrm{HCl}$, pH 7.4, $0.15 \mathrm{~m} \mathrm{NaCl}, 4$ mм EDTA, 4 mм EGTA, 1 mм Na $\mathrm{VO}_{4}, 50 \mathrm{~mm}$ $\mathrm{NaF}, 1 \mathrm{~mm}$ DTT, $2 \mu \mathrm{g} / \mathrm{ml}$ pepstatin A, and $1 \mu \mathrm{g} / \mathrm{ml}$ leupeptin. Materials insoluble in $0.5 \%$ Triton X-100 (the crude postsynaptic density fraction) were separated by centrifugation at 15,000 rpm for $10 \mathrm{~min}$. Measurement of CaMKII activity was performed as described previously (Fukunaga et al., 1989). PP1, PP2A, and PP2C activities were assessed as described previously (Fukunaga et al., 2000). Calcineurin (CaN) activity was assessed as described previously (Shioda et al., 2006).

Quantification of mRNA by real-time PCR. Total RNA were prepared from mPFC and whole hippocampus, hippocampal CA1, and dentate gyrus using TRIZOL Reagent. mRNA was reverse transcribed to single-stranded cDNA as described previously (Takeuchi and Fukunaga, 2003). Real-time PCR was performed in 48-well PCR plates (Mini Opticon Real-Time PCR System, Bio-Rad Laboratories) using iQ SYBR Green Supermix 2X (Bio-Rad Laboratories). Primer sequences were as follows: mouse PP $1 \gamma 1$ primers; 5'-CATCGACAGCATCATCCAAC-3', 5'-GGAAAGCCACCGTATTCAAA-3'; mouse GAPDH (glyceraldehyde 3-phosphate dehydrogenase) primers; 5'-TGTGTCCGTCGTGGATCTGA-3', 5' -CACCACCTTCTTGATGTCATCATAC- $3^{\prime}$. Relative quantities of the gene of interest were determined by the comparative threshold cycle $(\delta C T)$ method and normalized to GAPDH quantities. Purity and specificity of all products were confirmed by omitting the template and by performing a standard melting curve analysis.

Cell culture. Neonatal mouse cortical cell cultures were performed as previously described (Fukunaga et al., 1992). Briefly, cortexes were removed from mice at postnatal day 1 and placed in growth medium. Growth medium consisted of Eagle's minimum essential medium containing $10 \%$ fetal bovine serum, $10 \%$ horse serum, $2 \% \mathrm{Nu}$ serum, and $12 \mathrm{ng} / \mathrm{ml}$ nerve growth factor. Cells were mechanically dissociated by trituration with fire-polished Pasteur pipettes and seeded on a $35 \mathrm{~mm}$ dish coated with $0.01 \%$ poly-L-lysine (Sigma-Aldrich). One day after plating neurons, the culture medium was replaced by the growing medium lacking $10 \%$ fetal bovine serum, and cells were maintained in humidified $95 \%$ air and $5 \% \mathrm{CO}_{2}$ at $37^{\circ} \mathrm{C}$ for $14 \mathrm{~d}$. At 1 and $10 \mathrm{~d}$ after plating neurons, cultures were treated with 5 or $1 \mu \mathrm{M}$ cytosine- $\beta$-arabinofuranoside to prevent the replication of nonneuronal cells, respectively. For okadaic acid stimulation, the culture dishes were replaced with or without KN-93 (20 $\mu \mathrm{M}$, Sigma-Aldrich) dissolved in Krebs-Ringer HEPES (KRH) solution containing $128 \mathrm{~mm}$ $\mathrm{NaCl}, 5 \mathrm{~mm} \mathrm{KCl}, 1 \mathrm{~mm} \mathrm{NaHPO}, 1.2 \mathrm{~mm} \mathrm{MgSO}_{4}, 10 \mathrm{~mm}$ glucose, and $20 \mathrm{~mm}$ HEPES, pH 7.4. After incubation for $30 \mathrm{~min}$, cells were incubated with KRH with or without okadaic acid ( $1 \mu \mathrm{M}$; Wako). After incubation for $15 \mathrm{~min}$, the medium was quickly aspirated, and the plated cells were frozen on liquid $\mathrm{N}_{2}$.

Chronic KN-93 infusion into mPFC. Chronic KN-93 infusion into mPFC was performed as previously described (Shioda et al., 2010b). Briefly, KN-93 (30 nmol in total per mouse) or vehicle alone (wild-type or $A T R X^{\Delta E 2}$ mice) was infused into the right brain lateral ventricle for $14 \mathrm{~d}$ with a micro-osmotic pump (model 1004; flow rate, $0.11 \mu \mathrm{l} / \mathrm{h}$; Alzet Osmotic Pumps). The cannula was implanted stereotaxically at the following coordinates: anterior, $1.7 \mathrm{~mm}$; lateral, $0.5 \mathrm{~mm}$; depth, $2 \mathrm{~mm}$ (relative to the bregma and the surface of the brain).

Statistical evaluation. All values reported were expressed as means \pm SEM. Comparison between two experimental groups was made using the unpaired Student's $t$ test. For cumulative distribution of spine length and spine head diameter, the Kolmogorov-Smirnov (K-S) test was used. Data from Barnes maze test and contextual fear-conditioning test were analyzed using two-way ANOVA, followed by one-way ANOVA for each group and Dunnett's tests. $p<0.05$ was considered significant.

\section{Results}

\section{$A T R X^{\triangle \mathrm{E} 2}$ mice show impaired learning memory and cognitive function}

Deficits in cognitive function as well as increased anxiety are prominent features of X-linked mental retardation syndromes in humans. To better understand the role of ATRX in these behaviors, we analyzed learning memory and anxiety behaviors in $A T R X^{\Delta E 2}$ mice. Since there was no difference in spontaneous locomotor activity during a $24 \mathrm{~h}$ period observed between wild-type and $A T R X^{\Delta E 2}$ mice (data not shown), behavioral experiments were conducted during the daytime period. In a Y-maze test, $A T R X^{\Delta E 2}$ mice showed decreased 


\section{A Y-maze test}



B Novel object recognition test
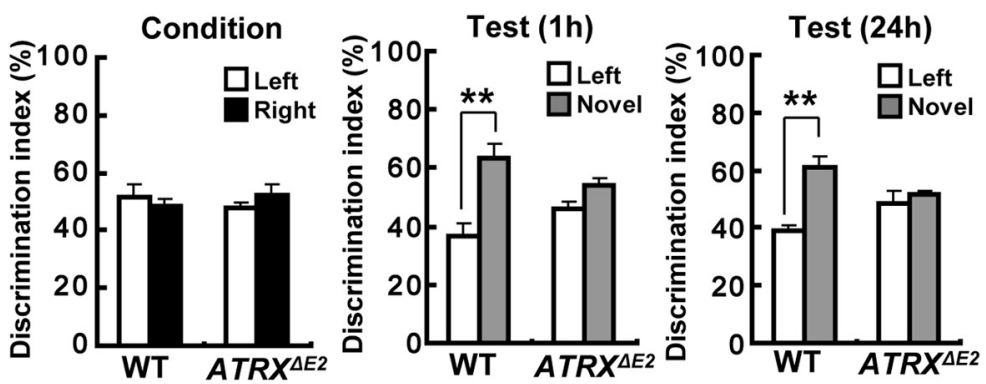

C Barnes-maze test

D Contextual fear conditioning
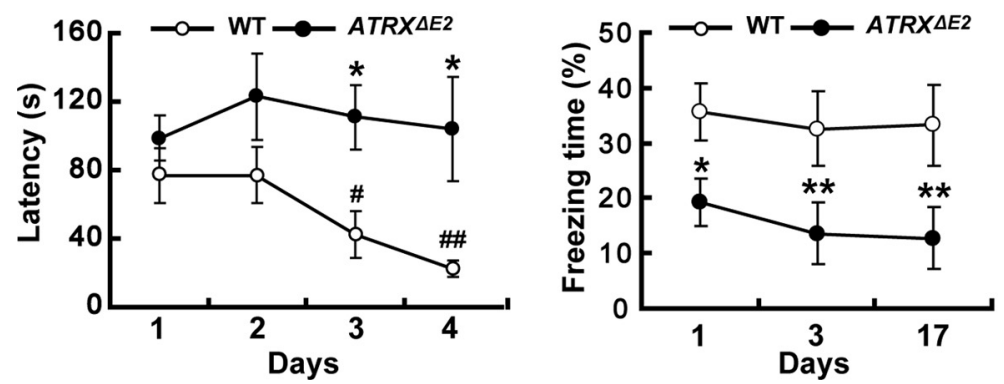

Figure 1. Impairment of memory and cognitive function-related behaviors in ATRX ${ }^{\triangle E 2}$ mice. $\boldsymbol{A}$, Alternations (left) and number of total arm entries (right) in a Y-maze test. Alternations by ATRX ${ }^{\Delta E 2}$ mice were significantly decreased compared with behavior seen in wild-type mice, without changes in total arm entries. Each bar represents the mean \pm SEM. ${ }^{* *} p<$ 0.01 versus wild-type mice; $n=10$ in each group. $\boldsymbol{B}$, Novel object recognition task. Shown is the discrimination index of object exploration during the sample phase (left), and while exploring familiar and new objects in the test phase after $1 \mathrm{~h}$ (center) and $24 \mathrm{~h}$ (right). Each bar represents the mean \pm SEM. ${ }^{* *} p<0.01$ versus the familiar objects, respectively; $n=$ 10 in each group. $C$, Barnes maze test measurement of total latency $(s)$ to reach the target hole. Each bar represents the mean \pm SEM. ${ }^{*} p<0.05$ versus wild-type mice, \#p $<0.05$, \#\#p $<0.01$ versus day 1 of the same group; $n=8-9$ in each group. $\boldsymbol{D}$, Contextual fear-conditioning test measurement of freezing time (\%). Each bar represents the mean \pm SEM. ${ }^{*} p<0.05,{ }^{* *} p<0.01$ versus wild-type mice; $n=10$ in each group. WT, Wild-type mice; ATRX ${ }^{\Delta E 2}$, ATRX ${ }^{\Delta E 2}$ mice.

alternation behavior (Fig. $1 A$, left) (wild-type mice, $70.3 \pm 2.2 \%$; $A T R X^{\Delta E 2}$ mice, $\left.49.3 \pm 4.0 \% ; t=4.63 ; n=10 ; p<0.01\right)$, with no effect seen in total number of arm entries (Fig. $1 \mathrm{~A}$, right), implying impaired spatial reference memory. In the novel object recognition test, the discrimination index did not differ between wild-type and $A T R X^{\Delta E 2}$ mice in the condition trial (Fig. $1 B$, left). However, in the test trial, $A T R X^{\Delta E 2}$ mice failed to discriminate a novel object from a familiar one at 1 and $24 \mathrm{~h}$ after the condition trial (Fig. $1 B$, center) ( $1 \mathrm{~h}$ : wild-type mice, $t=3.35, p<0.01$; $A T R X^{\Delta E 2}$ mice, $t=1.47, p=0.18, n=10$ each); (Fig. $1 B$, right) ( $24 \mathrm{~h}$ : wild-type mice, $t=3.86, p<0.01 ; A T R X^{\Delta E 2}$ mice, $t=0.43$, $p=0.68 ; n=10$ each). In the Barnes maze test, the latency time to enter into the target hole significantly decreased along 4 training days in wild-type mice, indicating normal improvement of cognitive performance (Fig. $1 C$ ). By contrast, the cognitive performance of $A T R X^{\Delta E 2}$ mice did not improve, as evidenced by significantly longer latency times than those seen in wild-type mice [genotype $\times$ day in latency time $\left(F_{(3,55)}=\right.$ $12.2, p=0.004)$; total latency time: wildtype mice, $218.7 \pm 13.6 \mathrm{~s} ; A T R X^{\Delta E 2}$ mice, $437 \pm 5.3 \mathrm{~s} ; p<0.01 ; n=9-10]$. Wildtype mice also significantly differed from $A T R X^{\Delta E 2}$ mice in number of errors [genotype $X$ day in number of error $\left(F_{(3,55)}=\right.$ 8.2, $p<0.05)$; total number of errors: wild-type mice, $21.4 \pm 1.1 ; A T R X^{\Delta E 2}$ mice, $32.8 \pm 0.7 ; p<0.05 ; n=9-10]$. To examine the memory formed by contextual fear conditioning, we measured the freezing time at $1 \mathrm{~d}, 3 \mathrm{~d}$ (recent memory), or $17 \mathrm{~d}$ (remote memory) after the footshock stimulation. Total freezing times were significantly lower in the $A T R X^{\Delta E 2}$ mice than those in the wild-type mice at $1 \mathrm{~d}$ as well as at $17 \mathrm{~d}$ (Fig. $1 D$ ) [genotype $X$ day in freezing time $\left(F_{(2,59)}=10.6, p=\right.$ $0.005) ; n=10$ each]. Finally, to evaluate unconditioned anxiety behavior, animals were tested in an elevated plus maze and light/dark transfer paradigms. No behavioral abnormality was observed between wild-type and $A T R X^{\Delta E 2}$ mice in unconditioned anxiety behaviors (data not shown). Together, ATRX ${ }^{\Delta E 2}$ mice exhibited impaired cognitive function and learning memory compared with wildtype mice, but no evidence of altered anxiety-like behavior.

\section{ATRX protein is expressed in both neuronal and glial cells}

To evaluate gross changes in brain between wild-type and $A T R X^{\Delta E 2}$ mice, we analyzed total brain weight and cell density. The brains of adult $A T R X^{\Delta E 2}$ mice did not display gross histological abnormalities, such as aberrations in cortical layer formation, but total brain weight was significantly lower in mutant compared with wild-type mice, consistent with the decreased body weight reported in Nogami et al. (2010) (Fig. 2A) (wild-type mice, $0.49 \pm 0.01 \mathrm{~g}$; $A T R X^{\Delta E 2}$ mice, $\left.0.46 \pm 0.01 \mathrm{~g} ; t=2.23 ; n=10 ; p<0.05\right)$. Cortical mPFC neurons are essential for normal cognitive performance related to working memory and attention (Morgan et al., 1993). Therefore, we analyzed pyramidal neurons of layer II/III, which have long ipsilateral and contralateral corticocortical (associative) projections. Also in monkeys, increases in action potential firing rates of this neuronal population are associated with cognitive performance (Schwartz and GoldmanRakic, 1984; Chang et al., 2005). Consistent with a previous in vitro study (McDowell et al., 1999), areas showing dense ATRX staining in wild-type mice colocalized with PI-bright nuclear regions in the mPFC region (Fig. $2 B$ ). Nuclear ATRX staining exhibited a punctate pattern coincident with the location of PIstained heterochromatin (Fig. 2B, top, high-magnification images). $A T R X^{\triangle E 2}$ mice showed decreased ATRX immunoreactivity (Fig. $2 B$, bottom). MAP-2 immunostaining revealed no differences in the length of primary dendrites in layer II/III pyra- 
A
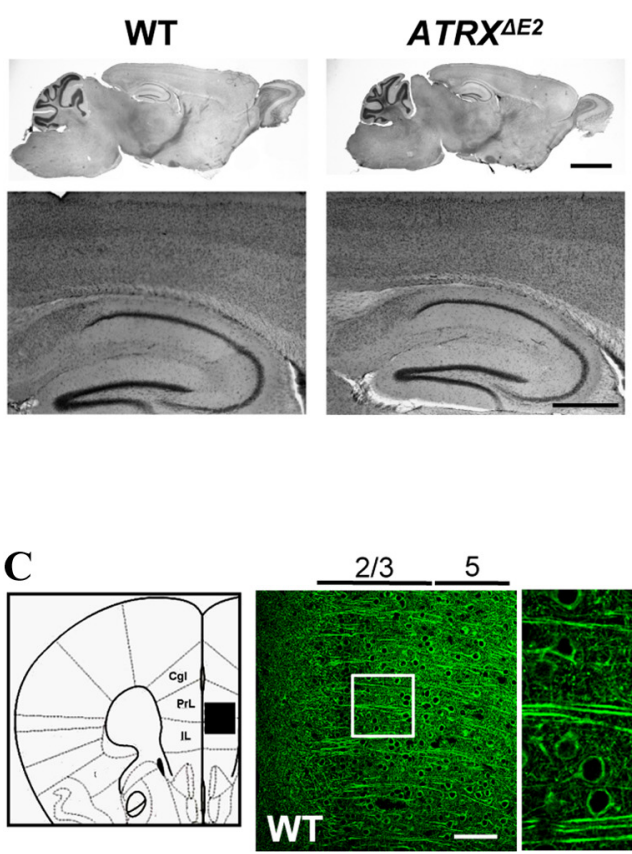

B
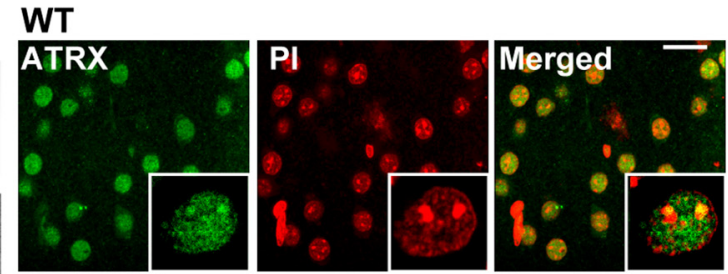

$\operatorname{ATRX}^{\Delta E 2}$

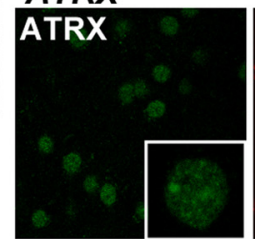

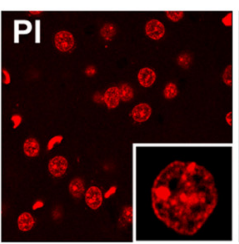

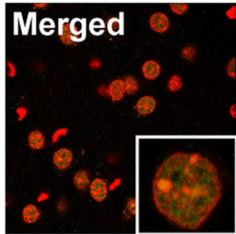

$2 / 3 \quad 5$
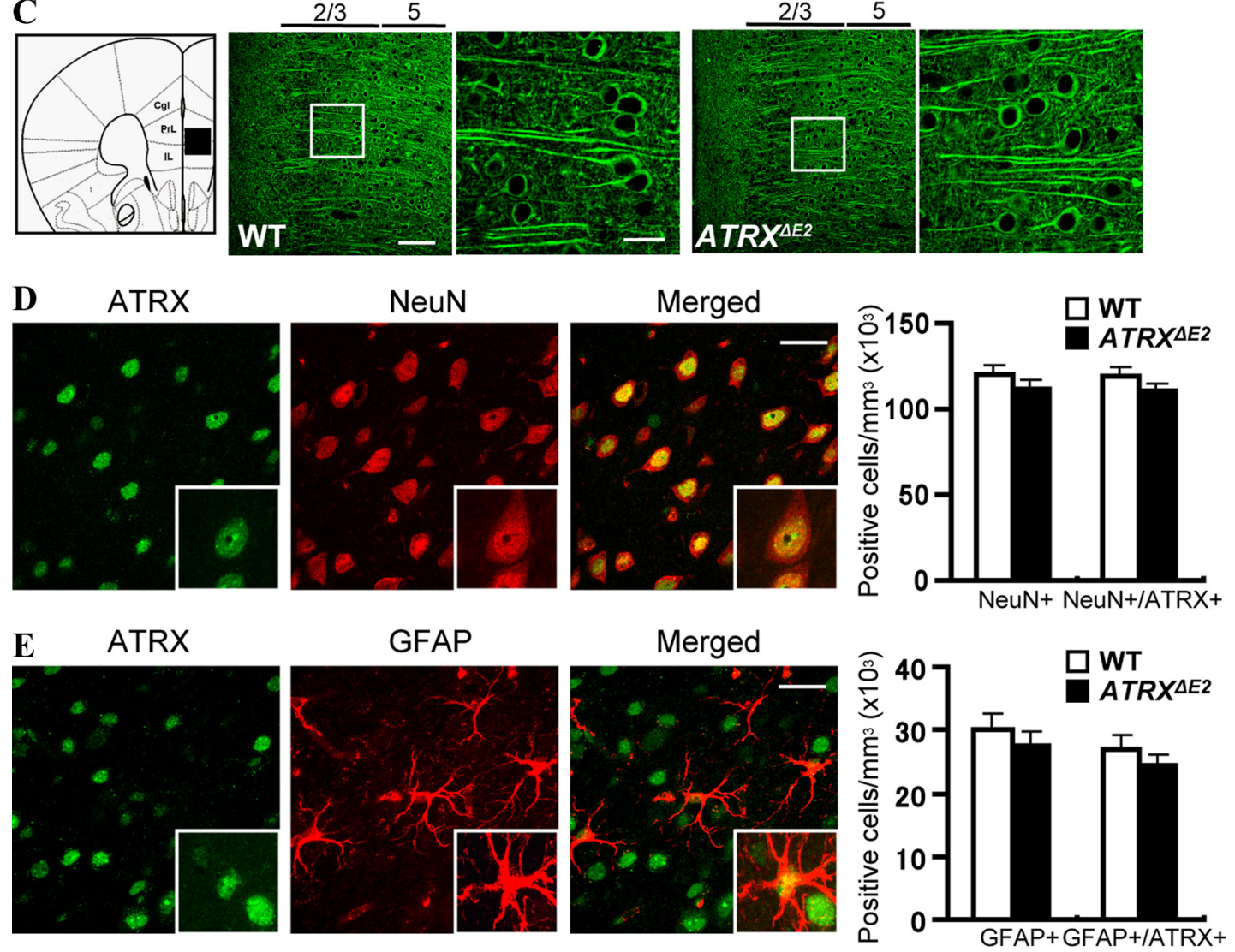

Figure 2. ATRX is expressed in mature neurons and astroglia. A, Hematoxylin and eosin staining of sagittal sections. ATRX ${ }^{\Delta E 2}$ mice exhibit normal gross morphology except for reduced brain size. $B$, ATRX staining is observed as punctate nuclear staining. Strong punctate staining colocalizes with heterochromatic regions stained with PI nuclear counterstain. C, The position of IL and PrL regions in the mPFC (left). MAP-2 immunostaining shows no gross differences in length of primary dendrites in layer II/IIl pyramidal neurons of $A T R X^{\triangle E 2}$ compared with wild-type mice. $D, E$, ATRXexpressing cells overlap with NeuN- (D) and GFAP- $(\boldsymbol{E})$ positive cells. Enlarged images indicate boxed area. Scale bars: $\boldsymbol{A}$, top, $2 \mathrm{~mm} ; \boldsymbol{A}$, bottom, $0.5 \mathrm{~mm} ; \boldsymbol{B}, \boldsymbol{D}, \boldsymbol{E}, 25 \mu \mathrm{m} ; \boldsymbol{C}$, low magnification, $80 \mu \mathrm{m}$; C, high magnification, $15 \mu \mathrm{m}$. WT, Wild-type mice; ATRX ${ }^{\triangle E 2}$, ATRX ${ }^{\triangle E 2}$ mice; NeuN +, NeuN-positive cells; GFAP+, GFAP-positive cells; NeuN + /ATRX+, NeuN and ATRX double-positive cells; GFAP+/ATRX +, GFAP and ATRX double-positive cells.

midal neurons in $A T R X^{\Delta E 2}$ mice compared with wild-type mice, and the densities of these fibers and branched dendritic trees were indistinguishable from those seen in wild-type mice (Fig. 2C). To analyze which cell types express ATRX in the MPFC, immunohistochemistry was performed using the cell-type-specific markers NeuN, which is expressed in nuclei of mature neurons, and GFAP, an astroglial marker. No significant change in the densities of NeuN- or GFAP-positive cells was observed in the mPFC region of wild-type and $A T R X^{\Delta E 2}$ mice (Fig. $2 D$ ) (NeuN-positive cells: wild-type mice, $120.7 \pm 5.0 \times 10^{3}$ cells $/ \mathrm{mm}^{3}$; ATRX $X^{\Delta E 2}$ mice, $112.2 \pm 4.8 \times 10^{3}$ cells $/ \mathrm{mm}^{3} ; p>0.05$ ) (Fig. $2 E$ ) (GFAPpositive cells: wild-type mice, $27.4 \pm 2.3 \times 10^{3}$ cells $/ \mathrm{mm}^{3}$; $A T R X^{\triangle E 2}$ mice, $30 \pm 2.7 \times 10^{3}$ cells $\left./ \mathrm{mm}^{3} ; p>0.05\right)$. Furthermore, almost all NeuN- or GFAP-positive cells expressed ATRX in both genotypes. We also measured MAP-2 and GFAP protein expression in the MPFC and observed no significant differences in expression levels of either marker between wildtype and $A T R X^{\triangle E 2}$ mice (data not shown). These data indicate that ATRX is expressed exclusively in the nucleus of both mature neurons and astroglial cells. 
A
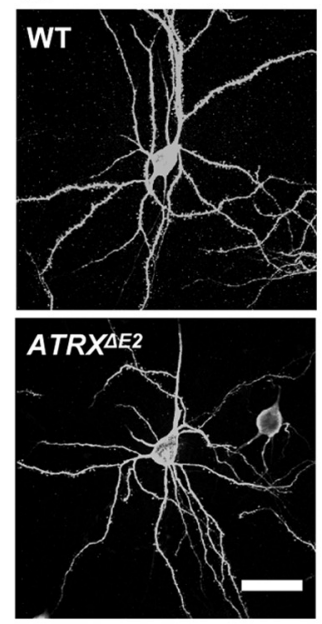

C

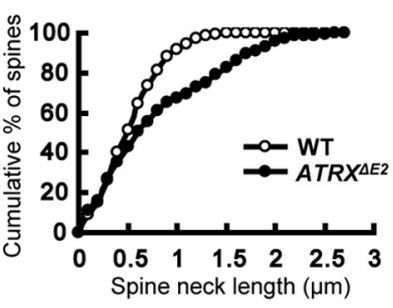

E

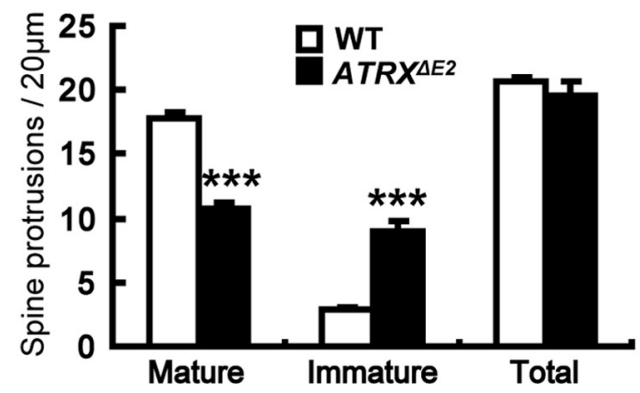

Figure 3. Abnormal spines in the $\mathrm{mPFC}$ of $A T R X^{\triangle E 2}$ mice. $\boldsymbol{A}, \boldsymbol{B}$, Low-magnification images $(\boldsymbol{A})$ and morphology of apical dendrites $(\boldsymbol{B})$ in wild-type and $A T R X^{\triangle E 2}$ mice. At the bottom, enlarged images indicate boxed areas of tissues from wild-type and $A T R X^{\triangle E 2}$ mice. $\boldsymbol{C}-\boldsymbol{E}$, Quantitative analysis of apical spine morphology in wild-type (white circles and white bars) and $A_{T R X}{ }^{E 2}$ (black circles and black bars) mice. C, D, Cumulative distribution of spine neck length (C) and spine head diameter (D).E, Spine protrusions per $20 \mu \mathrm{m}$ dendritic length. ATRX $X^{\Delta E 2}$ mice exhibit significantly more immature- and fewer mature-appearing spines, without changes in total spine density. Each bar represents the mean \pm SEM. ${ }^{* * *} p<0.001$ versus wild-type mice. Scale bars: $\boldsymbol{A}, 30 \mu \mathrm{m} ; \boldsymbol{B}, 4 \mu \mathrm{m}$. WT, Wild-type mice; $\operatorname{ATRX}^{\Delta E 2}$, $\operatorname{ATRX}^{\Delta E 2}$ mice.

$A T R X^{\Delta} \mathrm{E} 2$ mice exhibit abnormal dendritic spines in the mPFC, but not in hippocampal CA1 neurons $A T R X^{\triangle E 2}$ mice showed impairments of cognitive functions and spatial memory. Since mPFC and hippocampus are involved in cognition and spatial memory (Brown and Aggleton, 2001; Frankland and Bontempi, 2005), we investigated whether $A T R X^{\Delta E 2}$ mice change in structure of the dendritic spines in the MPFC and hippocampus. In LY-injected pyramidal neurons of the mPFC, abnormal thin and long spines resembling filopodia were observed in $A T R X^{\triangle E 2}$ mice (Fig. $3 A, B$ ) compared with wild-type mice. In apical dendrites, the spine length distribution was shifted to the right in $A T R X^{\triangle E 2}$ compared with wild-type mice, indicating a higher proportion of long and filopodia-like spines in $A T R X^{\triangle E 2}$ mice (Fig. $\left.3 C\right)(n=2880$ spines from three wild-type mice; $n=2754$ spines from three $A T R X^{\Delta E 2}$ mice; $p<0.001$, K-S test) (mean spine length: wild-type mice, $0.62 \pm 0.01 \mu \mathrm{m}$; $A T R X^{\Delta E 2}$ mice, $0.88 \pm 0.03 \mu \mathrm{m} ; p<0.001, t$ test). The spine head diameter distribution was shifted toward lower values in $A T R X^{\triangle E 2}$ compared with wild-type mice (Fig. $\left.3 D\right)(p<0.001$, K-S test) (mean spine head diameter: wild-type mice, $0.48 \pm 0.01$ $\mu \mathrm{m} ; A T R X^{\Delta E 2}$ mice, $0.39 \pm 0.01 \mu \mathrm{m} ; p<0.01, t$ test). As shown in Figure $3 E, A T R X^{\triangle E 2}$ mice showed increased numbers of immature-appearing and fewer mature-appearing spines than did their wild-type counterparts (mature-appearing spines: wildtype mice, 17.8 spines $/ 20 \mu \mathrm{m}$ dendrite length; $A T R X^{\Delta E 2}$ mice, 10.7 spines $/ 20 \mu \mathrm{m}$ dendrite length; $p<0.001$; immatureappearing spines: wild-type mice, 2.8 spines $/ 20 \mu \mathrm{m}$ dendrite length; $A T R X^{\triangle E 2}$ mice, 8.9 spines $/ 20 \mu \mathrm{m} ; p<0.001$ ) without a change in total spine numbers (wild-type mice, 20.7 spines/20 $\mu \mathrm{m} ;$ ATRX $^{\Delta E 2}$ mice, 19.6 spines $/ 20 \mu \mathrm{m} ; p=0.16$ ).

Similar results were obtained when we analyzed basal dendritic spines in the mPFC (Fig. $4 A-D$ ). Cumulative percentage of spines in spine neck length was changed in $A T R X^{\triangle E 2}$ mice compared with wild-type mice (Fig. $4 B)(n=4413$ spines from three wild-type mice; $n=4257$ spines from three $A T R X^{\Delta E 2}$ mice; $p<$ $0.001, \mathrm{~K}-\mathrm{S}$ test) (mean spine neck length: wild-type mice, $0.65 \pm$ $0.01 \mu \mathrm{m} ; A T R X^{\Delta E 2}$ mice, $0.96 \pm 0.03 \mu \mathrm{m} ; p<0.001, t$ test $)$. The spine head diameter distribution was shifted toward lower values in $A T R X^{\triangle E 2}$ mice compared with wild-type mice (Fig. $\left.4 C\right)(p<$ 0.001 , K-S test) (mean spine head diameter: wild-type mice, $0.48 \pm 0.01 \mu \mathrm{m} ; A T R X^{\Delta E 2}$ mice, $0.39 \pm 0.01 \mu \mathrm{m} ; p<0.01$ ). $A T R X^{\Delta E 2}$ mice showed more immature-appearing and fewer mature-appearing spines than their wild-type counterparts (Fig. 4D) (mature-appearing spines: wild-type mice, 18.1 spines/20 $\mu \mathrm{m}$ dendrite length; $A T R X^{\Delta E 2}$ mice, 10.9 spines/20 $\mu \mathrm{m}$ dendrite length; $p<0.001$; immature-appearing spines: wild-type mice, 3.3 spines $/ 20 \mu \mathrm{m}$; $A T R X^{\Delta E 2}$ mice, 8.8 spines $/ 20 \mu \mathrm{m} ; p<0.001$ ), without changes in total spine number (wild-type mice, 21.4 spines/20 $\mu \mathrm{m}$; $A T R X^{\Delta E 2}$ mice, 19.7 spines $/ 20 \mu \mathrm{m} ; p=0.09$ ). Abnormal thin and long immature spines were observed in $A T R X^{\triangle E 2}$ mice, whereas, there was no significant difference in the number of basal dendritic branches between wild-type and $A T R X^{\triangle E 2}$ mice (wild-type mice, $10.2 \pm 0.43 ; A T R X^{\Delta E 2}$ mice, $9.75 \pm 0.41 ; p=0.25)$.

Furthermore, we examined the spine morphology of basal dendritic spines in hippocampal CA1 neurons. There were no significant changes in the spine neck length and spine head diameter in hippocampal CA1 neurons between wild-type and $A T R X^{\Delta E 2}$ mice (Fig. $4 E-H$ ). The relationship of the cumulative percentage of spines to spine neck length is shown in Figure $4 F$ ( $n=3577$ spines from three wild-type mice; $n=3850$ spines from three $A T R X^{\triangle E 2}$ mice; $p>0.05$, K-S test) (mean spine neck length: wild-type mice, $0.77 \pm 0.02 \mu \mathrm{m}$; ATRX $X^{\Delta E 2}$ mice, $0.79 \pm$ $0.02 \mu \mathrm{m} ; p>0.05)$. The relationship of the cumulative percentage of spines to spine head diameter distribution is shown in Figure $4 G(p>0.05$, K-S test) (mean spine head diameter: wildtype mice, $0.46 \pm 0.02 \mu \mathrm{m}$; ATRX $X^{\Delta E 2}$ mice, $0.44 \pm 0.02 \mu \mathrm{m} ; p>$ 0.05 ). Spine protrusions are shown in Figure $4 H$ (mature: wildtype mice, 19.7 spines $/ 20 \mu \mathrm{m}$ dendrite length; $A T R X^{\Delta E 2}$ mice, 18.2 spines $/ 20 \mu \mathrm{m}$ dendrite length; $p>0.05$ ) (immature: wildtype mice, 3.0 spines $/ 20 \mu \mathrm{m}$; $A T R X^{\Delta E 2}$ mice, 3.2 spines $/ 20 \mu \mathrm{m}$; $p>0.05$; total: wild-type mice, 22.7 spines $/ 20 \mu \mathrm{m}$; $A T R X^{\Delta E 2}$ mice, 21.5 spines $/ 20 \mu \mathrm{m} ; p>0.05$ ).

CaMKII autophosphorylation is significantly increased in the mPFC of $A T R X \Delta \mathrm{E} 2$ mice

Since we previously found that injection of active autophosphorylated CaMKII into pyramidal neurons increases filopodia-like 
spines (Jourdain et al., 2003), we analyzed CaMKII autophosphorylation both in total homogenates and in fractions containing crude PSDs in the mPFC of $A T R X^{\Delta E 2}$ mice. First, we confirmed our previous observation of markedly decreased levels of ATRX protein in $A T R X^{\Delta E 2}$ mice (Fig. $2 B$ ) (Nogami et al., 2010) and found that ATRX protein expression in $A T R X^{\Delta E 2}$ mouse mPFC was reduced to $30 \%$ of wildtype levels (Fig. 5B) $(t=5.75, p<0.01$, $n=6)$. Interestingly, autophosphorylation of both CaMKII $\alpha$ and $\beta$ subunits was markedly increased (Fig. 5B) ( $\alpha$ subunit: $148.7 \pm 9.2 \%, t=3.43 ; \beta$ subunit: $192.9 \pm 24.4 \%, t=3.79 ; p<0.05 ; n=6$ each) without changes in protein levels of either isoform. We also analyzed protein kinase activities of other $\mathrm{Ca}^{2+} / \mathrm{CaM}$ dependent protein kinases, such as CaMKI and CaMKIV, and of $\mathrm{Ca}^{2+}$ regulated protein kinases, such as ERK and PKC $\alpha$. We found no significant differences in these protein kinase activities between wild-type and $A T R X^{\Delta E 2}$ mice in total mPFC homogenates (data not shown). Since CaMKII is localized in PSD, where it accumulates in response to NMDA receptor stimulation (Shen and Meyer, 1999; Kennedy, 2000), we measured levels of CaMKII autophosphorylation in Triton $\mathrm{X}$-100-insoluble fractions containing PSDs (Fig. 5C). As expected, CaMKII autophosphorylation was significantly increased in Triton X-100 insoluble fractions obtained from $A T R X^{\Delta E 2}$ mouse mPFC compared with wild-type mice. However, a slight increase in CaMKII autophosphorylation was also seen in soluble fractions from the $A T R X^{\Delta E 2}$ mouse mPFC. We further confirmed increased CaMKII activity by measuring $\mathrm{Ca}^{2+}$-independent CaMKII activity in both Triton X-100-soluble and -insoluble fractions. Consistent with immunoblotting results, a large increase in $\mathrm{Ca}^{2+}$-independent CaMKII activity was found in the insoluble fraction with a small increase in the soluble fraction (Fig. $5 E$ ) (insoluble fraction: $162.1 \pm 10.3 \%, t=4.2$, $p<0.01$; soluble fraction: $128.9 \pm 8.7 \%, t=3.22, p<0.05 ; n=6$ each).

\section{Phosphorylation of Rac1-GEFs pathway is increased in} ATRX $\Delta \mathrm{E} 2$ mice

GEF activity of Tiam1 toward Racl is enhanced through Tiam1 phosphorylation by CaMKII (Fleming et al., 1999), and Tiam1 phosphorylation is coupled to NMDA receptor stimulation in cultured cortical neurons (Tolias et al., 2005). Furthermore, kalirin-7, another GEF toward Rac1, is also phosphorylated by CaMKII at residues Thr95 and Thr778 (Xie et al., 2007). Therefore, we asked whether Tiam1 and kalirin-7 phosphorylation was elevated in $A T R X^{\Delta E 2}$ mouse. When we performed immunoblotting of immunoprecipitated Tiam1 and kalirin with an anti phospho-Ser/Thr an-

\section{Basal dendritic spines in mPFC}

A
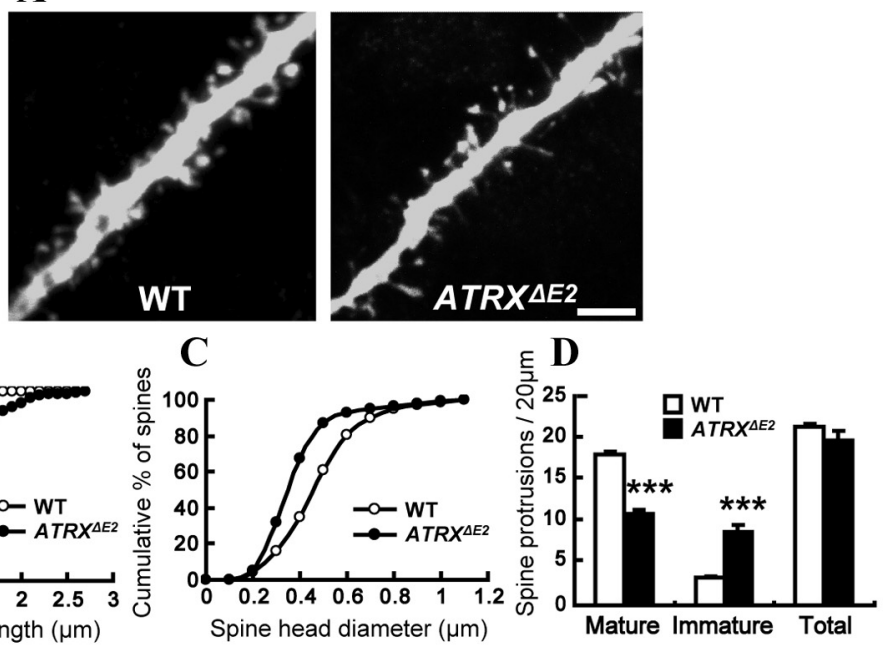

\section{Basal dendritic spines in hippocampal CA1 neurons} E
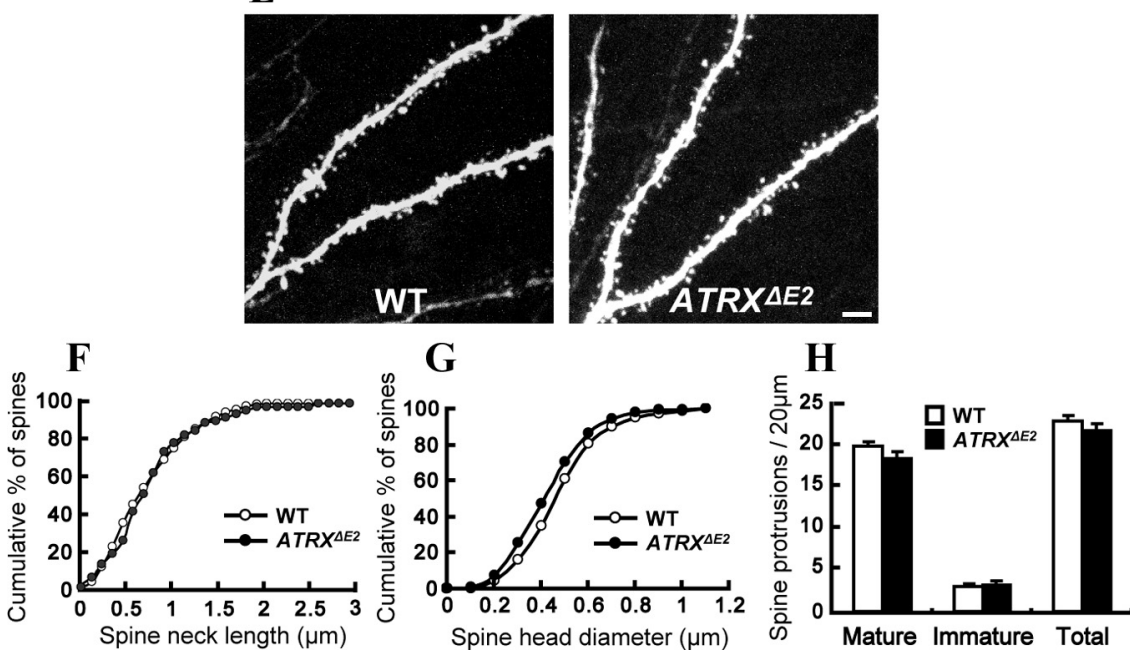

Figure 4. Abnormal basal dendritic spines in the $\mathrm{mPFC}$, but not in the hippocampal CA1 neurons of $A T R X^{\triangle E 2}$ mice. $\boldsymbol{A}, \boldsymbol{E}$, Morphology of basal dendrites in wild-type and $A T R X^{\triangle E 2}$ mice. $\boldsymbol{B}-\boldsymbol{D}, \boldsymbol{F}-\boldsymbol{H}$, Quantitative analysis of morphology of basal dendritic spines in wild-type (white circles and white bars) and $A T R X^{\triangle E 2}$ (black circles and black bars) mice. $B, C, F, G$, Cumulative distribution 政 protrusions per $20 \mu \mathrm{m}$ dendritic length in $\mathrm{mPFC}(\boldsymbol{D})$ in hippocampal $\mathrm{CA} 1(\boldsymbol{H})$. Each bar represents the mean \pm SEM. ${ }^{* * *} p<0.001$ versus the wild-type mice. Scale bars, $2 \mu \mathrm{m}$. WT, Wild-type mice; $\operatorname{ATRX}^{\triangle E 2},{ }^{A T R X}{ }^{\triangle E 2}$ mice.

tibody, we observed that phosphorylation of Tiam1 $(t=4.63, p<$ $0.01, n=6)$ and kalirin-7 $(t=3.92, p<0.01, n=6)$ was markedly enhanced in $A T R X^{\Delta E 2}$ mouse compared with wildtype mice, but no changes were seen in total protein levels (Fig. $6 A$ ). These results suggest that Tiam 1 and kalirin-7 phosphorylation is likely enhanced by elevated CaMKII activity in the mPFC of the $A T R X^{\Delta E 2}$ mouse.

Activation of Rac1 by GEFs such as Tiam 1 and kalirin-7 likely stimulates PAKs (Bokoch, 2003). We thus determined autophosphorylation and concomitant activation of PAKs (PAK1, PAK2, and PAK3) (Manser et al., 1995; Lei et al., 2000). Immunoblotting with phospho-specific antibodies recognizing $p$-PAK1/3 (Thr421/ Thr423; $t=3.87, p<0.05, n=6$ ) and $p$-PAK2 (Thr402; $t=5.21$, $p<0.01, n=6$ ) revealed significant increases in phospho-proteins in $A T R X^{\Delta E 2}$ mice compared with wild-type mice, with no changes in total protein (Fig. 6B). 

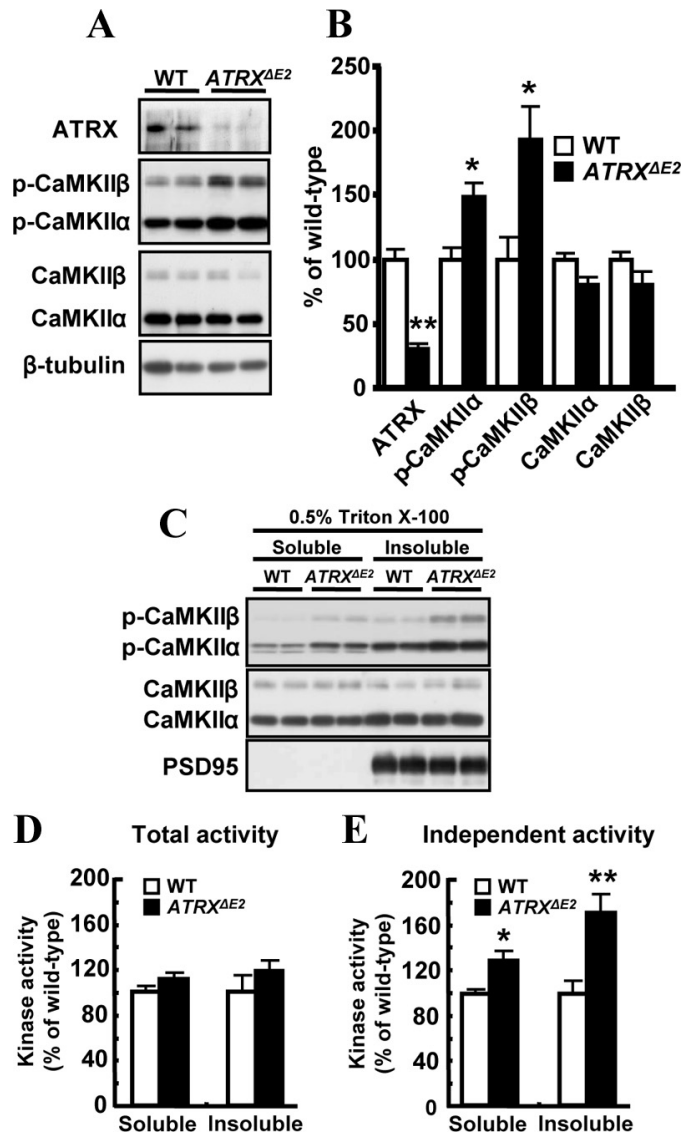

Figure 5. CaMKII autophosphorylation is significantly increased in $A T R X^{\Delta E 2}$ mice. $\boldsymbol{A}, \boldsymbol{C}$, Representative immunoblots probed with various antibodies are shown in total lysate $(\boldsymbol{A})$ and in Triton X-100-soluble or -insoluble fractions ( $C$ ) from mPFC. $\boldsymbol{B}$, Quantitative analyses by densitometry are shown. $\boldsymbol{D}, \boldsymbol{E}$, Increased $\mathrm{Ca}^{2+}$-independent activity of CaMKII in the MPFC of $A T R X^{\triangle E 2}$ mice. Data are expressed as a percentage of the value of wild-type mice. Each bar represents the mean \pm SEM. ${ }^{*} p<0.05,{ }^{* *} p<0.01$ versus the wild-type mice; $n=6$ in each group. WT, Wild-type mice; $\operatorname{ATRX}^{\Delta E 2},{ }^{A T R} X^{\Delta E 2}$ mice.

We confirmed PAK activation by analyzing phosphorylation of MLC (Ramos et al., 1997). Immunoblot analysis indicated that MLC (Ser 19) phosphorylation was markedly increased $(t=4.81$, $p<0.01, n=6)$ without changes in MLC protein in $A T R X^{\Delta E 2}$ mouse (Fig. 6C). Spines are highly specialized F-actin-rich dendritic protrusions that contain spinophilin, and F-actin- and PP1-binding protein (Allen et al., 1997). Spinophilin protein expression level was significantly decreased in $A T R X^{\Delta E 2}$ mice $(t=$ 2.88, $p<0.05, n=6$ ). In contrast with the markedly increased activities of CaMKII and PAKs, protein expression levels of other postsynaptic, plasticity-related proteins, including PSD95, NR1, and GluR1, and of the presynaptic protein synapsin 1, were unchanged in $A T R X^{\Delta E 2}$ mice (Fig. $6 C$ ). These results indicate that aberrant CaMKII activation and elevation of Rac1-GEF/PAK signaling occurs in the mPFC of $A T R X^{\Delta E 2}$ mice in the absence of changes in levels of synapse-associated proteins.

\section{PP1 expression and activity significantly decrease in ATRX $\Delta \mathrm{E} 2$ mice}

Since PP1 (Schworer et al., 1986), PP2A (Lai et al., 1986), and PP2C (Fukunaga et al., 1993) can dephosphorylate autophosphorylated CaMKII, we hypothesized that changes in activities of these protein phosphatases underlie increased CaMKII activity in $A T R X^{\Delta E 2}$ mice. As expected, protein expression levels of the catalytic $\gamma$ subunit of PP1, which is highly localized to PSD and dendritic spines (Ouimet et al., 1995), were selectively decreased $(61.5 \pm 6.3 \%, t=3.53, p<0.01, n=6)$ without changes in other protein phosphatases, including the PP2A catalytic subunit and CaN (Fig. $7 A, B$ ). Decreased PP1 plus PP2A activity was observed in Triton $\mathrm{X}$-100-insoluble fractions from $A T R X^{\Delta E 2}$ mice (Fig. 7C) $(62.8 \pm 10.6 \%, t=3.34, p<0.01, n=6)$. Activities of PP1 plus PP2A $(90.5 \pm 2.65 \%, t=1.99, p=0.1$, $n=6), \mathrm{CaN}(83.2 \pm 6.9 \%, t=1.61, p=0.073, n=6)$, and PP2C $(91.4 \pm 2.0 \%, t=2.45, p=0.069, n=6)$ in the Triton $\mathrm{X}$-100-soluble fraction were also slightly decreased in $A T R X^{\Delta E 2}$ mice compared with wild-type mice, but those changes were not statistically significant. Real-time PCR analysis showed that mRNA expression of PP $1 \gamma 1$ was significantly decreased in $\mathrm{mPFC}$ of $A T R X^{\Delta E 2}$ mice $(78.1 \pm 6.9 \%, t=2.63$, $p<0.05, n=9-10)$, but not in hippocampus, hippocampal CA1, and dentate gyrus ( $p>0.05, n=9-10$ each).

Increased phosphorylation of Tiam 1 and kalirin-7 by okadaic acid is inhibited by $\mathrm{KN}-93$ in cultured cortical neurons

To confirm involvement of CaMKII activity in phosphorylation of Tiam 1 and kalirin-7, we examined whether KN-93, a CaMKII inhibitor, inhibits phosphorylation of Tiam 1 and kalirin-7 in cultured cortical neurons. The CaMKII activity/autophosphorylation was stimulated by treatment with okadaic acid, a protein phosphatase PP1/2A inhibitor (Fig. 8A,B) ( $\alpha$ subunit: $176.9 \pm$ $33.6 \%, t=2.65$; $\beta$ subunit: $173.9 \pm 24.2 \%, t=2.7, p<0.05, n=$ 5 each) without changes in total CaMKII proteins. Concomitant with the increase in CaMKII autophosphorylation, the phosphorylation of Tiam $1(t=2.84, p<0.05)$ and kalirin-7 $(t=4.47$, $p<0.01$ ) was significantly increased following okadaic acid treatment. The phosphorylation of downstream targets PAK $(t=$ $2.54, p<0.05)$ and MLC $(t=2.6, p<0.05)$ was also significantly enhanced by okadaic acid without changes in the total protein level of each (Fig. $8 A, B)(n=5$ each). As expected, KN93 (20 $\mu \mathrm{M})$ treatment totally inhibited the increased CaMKII autophosphorylation by okadaic acid ( $\alpha$ subunit: $102 \pm 13.4 \%, t=2.55 ; \beta$ subunit: $116.1 \pm 12.8 \%, t=2.58$; $p<0.05$ ). Similarly, the increased phosphorylation of Tiam $1(t=2.9, p<0.05)$, kalirin-7 $(t=3.76, p<0.01), \operatorname{PAK}(t=2.51, p<0.05)$, and MLC $(t=2.64$, $p<0.05)(n=5$ each $)$ was inhibited by KN-93 treatment.

\section{Abnormal spine morphology in $A T R X \Delta \mathrm{E} 2$ mice is inhibited by $\mathrm{KN}-93$ infusion into $\mathrm{mPFC}$}

We finally confirmed whether inhibition of CaMKII activity with chronic KN-93 administration reverses abnormal dendritic spine morphology observed in $\mathrm{mPFC}$ of $A T R X^{\Delta E 2}$ mice. In apical dendritic spines, $\mathrm{KN}-93$ infusion into $\mathrm{MPFC}$ partly reversed the generation of long-neck spines observed in $A T R X^{\Delta E 2}$ mice (Fig. $8 C$ ) ( $n=2234$ spines from three wild-type mice, $n=2451$ spines from three $A T R X^{\Delta E 2}$ mice; $n=1900$ spines from three KN-93treated $A T R X^{\Delta E 2}$ mice; $p<0.01$, K-S test, for $A T R X^{\Delta E 2}$ mice vs KN-93-treated $A T R X^{\Delta E 2}$ mice) (mean spine length: wild-type mice, $0.64 \pm 0.02 \mu \mathrm{m}$; ATRX ${ }^{\Delta E 2}$ mice, $0.91 \pm 0.03 \mu \mathrm{m}$, KN-93treated $A T R X^{\Delta E 2}$ mice, $0.75 \pm 0.03 \mu \mathrm{m} ; p<0.01, t$ test, for $A T R X^{\Delta E 2}$ vs KN-93-treated $A T R X^{\Delta E 2}$ mice). The KN-93 infusion also partly inhibited the generation of thin head spines observed in $A T R X^{\Delta E 2}$ mice (Fig. 8D) $\left(p<0.01\right.$, K-S test, for $A T R X^{\Delta E 2}$ mice vs KN-93-treated $A T R X^{\Delta E 2}$ mice) (mean spine head diameter: wild-type mice, $0.45 \pm 0.02 \mu \mathrm{m} ; A T R X^{\Delta E 2}$ mice, $0.38 \pm 0.02 \mu \mathrm{m}$; KN-93-treated $A T R X^{\Delta E 2}$ mice, $0.42 \pm 0.02 \mu \mathrm{m} ; p<0.01, t$ test, for $A T R X^{\Delta E 2}$ mice vs KN-93-treated $A T R X^{\Delta E 2}$ mice). As expected, KN-93 infusion into $A T R X^{\Delta E 2}$ mice moderately but significantly reduced the number of immature spines without a 

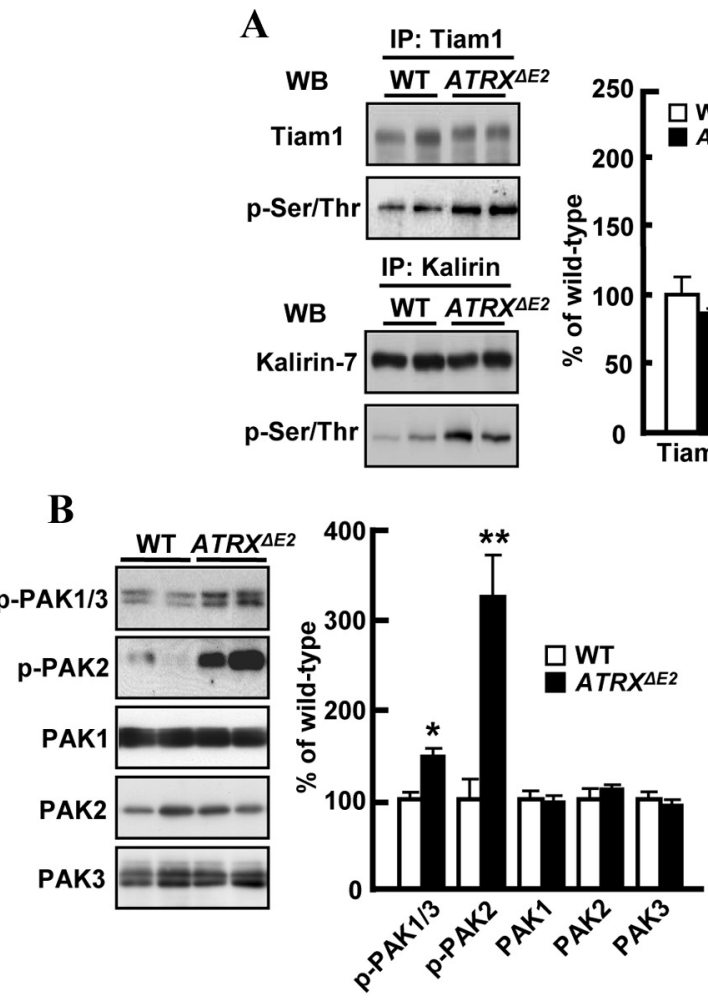
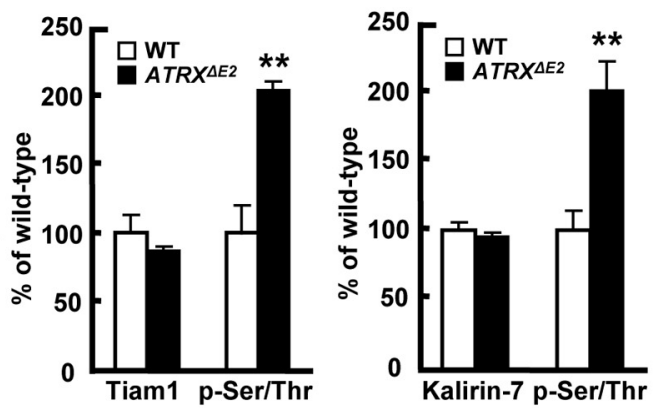

C

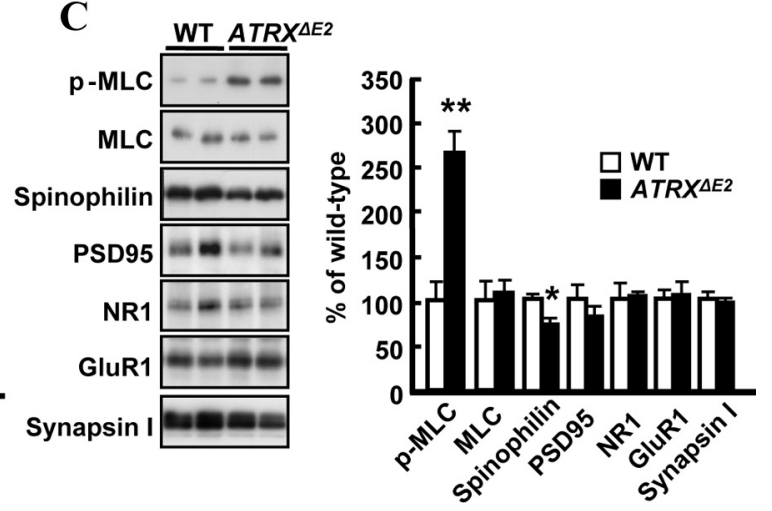

Figure 6. Phosphorylation of Rac1-GEF/PAK pathway is significantly increased in ATRX ${ }^{\triangle E 2}$ mice. $A$, Left, Representative immunoblots probed with various antibodies are shown. Extracts made from mPFC were immunoprecipitated (IP) using anti-Tiam1 and anti-kalirin antibodies, and immunoprecipitates were analyzed by Western blotting (WB) with anti-pSer/Thr antibody. Right, Quantitative densitometry analyses are shown. $B, C$, Left, Representative immunoblots probed with various antibodies are shown in total lysate from $m$ PFC. Right, Quantitative densitometry analyses are shown. Data are expressed as percentage of value of wild-type mice. Each bar represents the mean $\pm S E M .{ }^{*} p<0.05,{ }^{* *} p<0.01$ versus the wild-type mice; $n=6$ in each group. WT, Wild-type mice; $\operatorname{ATRX}^{\triangle E 2}, \operatorname{ATRX}^{\triangle E 2}$ mice.
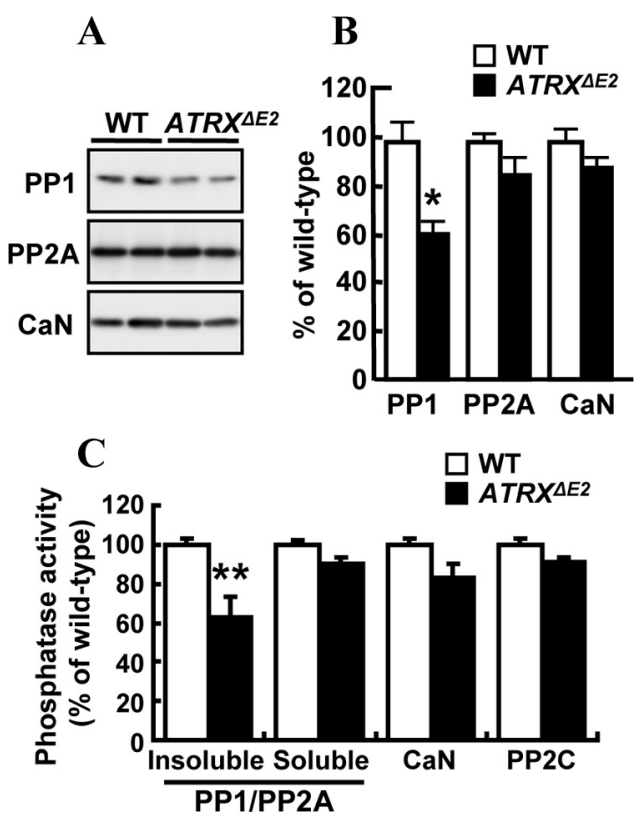

Figure 7. Expression and activity of protein phosphatase 1 are decreased in $A T R X^{\triangle E 2}$ mice. $A$, Representative immunoblots probed with various antibodies are shown in total Iysate from $\mathrm{mPFC}$. B, Quantitative densitometry analyses are shown. C, Decreased PP1/ PP2A activity in the mPFC of $A T R X^{\triangle E 2}$ mice. Data are expressed as percentage of value of wild-type mice. Each bar represents the mean $\pm S E M .{ }^{*} p<0.05,{ }^{* *} p<0.01$ versus the wild-type mice, $n=6$ in each group. WT, Wild-type mice; $A T R X^{\Delta E 2}, A T R X^{\Delta E 2}$ mice. change in mature spine number (mature spines: wild-type mice, 18.3 spines $/ 20 \mu \mathrm{m}$ dendrite length; $A T R X^{\Delta E 2}$ mice, 10.5 spines $/ 20$ $\mu \mathrm{m}$ dendrite length; $\mathrm{KN}$-93-treated $A T R X^{\Delta E 2}$ mice, 9.6 spines/20 $\mu \mathrm{m}$ dendrite length; $p=0.14$ for $A T R X^{\Delta E 2}$ mice vs KN-93treated $A T R X^{\Delta E 2}$ mice; immature spines: wild-type mice, 3.3 spines $/ 20 \mu \mathrm{m}$ dendrite length, $A T R X^{\Delta E 2}$ mice 9.4 spines $/ 20 \mu \mathrm{m}$ dendrite length; KN-93-treated $A T R X^{\Delta E 2}$ mice, 6.7 spines $/ 20 \mu \mathrm{m}$ dendrite length; $p<0.05$ for $A T R X^{\Delta E 2}$ mice vs KN-93-treated $A T R X^{\Delta E 2}$ mice). Thus, the total number of spines moderately reduced by KN-93 infusion (total spines: wild-type mice, 21.7 spines $/ 20 \mu \mathrm{m}$ dendrite length; $A T R X^{\Delta E 2}$ mice, 19.9 spines $/ 20 \mu \mathrm{m}$ dendrite length; KN-93-treated $A T R X^{\Delta E 2}$ mice, 16.3 spines/20 $\mu \mathrm{m}$ dendrite length; $p<0.05$ for $A T R X^{\Delta E 2}$ mice vs KN-93treated $A T R X^{\Delta E 2}$ mice). Together, inhibition of CaMKII activity by KN-93 infusion in vivo partly prevented the generation of abnormal thin and long spines observed in $A T R X^{\Delta E 2}$ mice.

\section{Discussion}

The critical finding reported in the present study is that aberrant dendritic spine formation occurs in the mPFC of $A T R X^{\Delta E 2}$ mouse brain, a mouse mutant representative of mutations seen in a human disorder associated with mental retardation. Long and thin spine formation likely underlies deficits of learning and cognitive function observed in $A T R X^{\Delta E 2}$ mice. The second significant observation is that aberrant CaMKII activation is associated with abnormal spine formation through elevated PAK activities via Tiam 1 and kalirin-7 phosphorylation. Finally, reduced PP1 protein levels and activity likely mediate in part aberrant CaMKII activation in the mPFC (Fig. 9). 
A

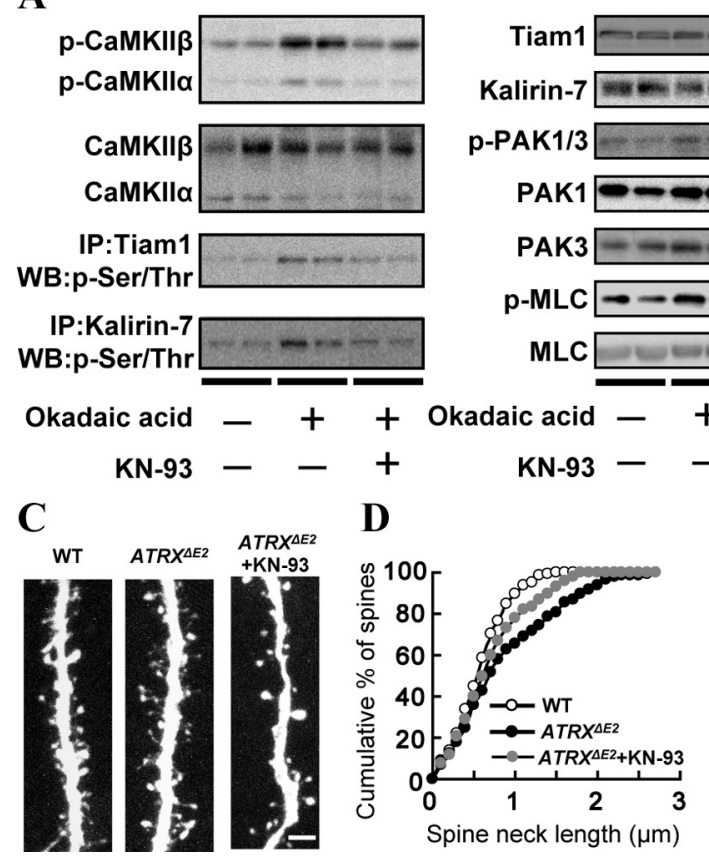

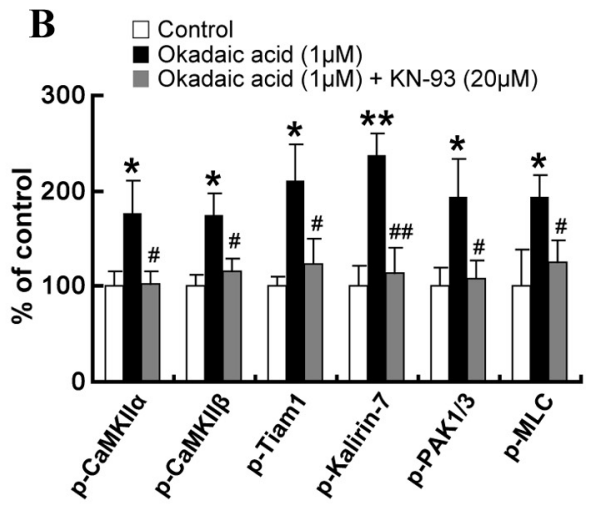

E
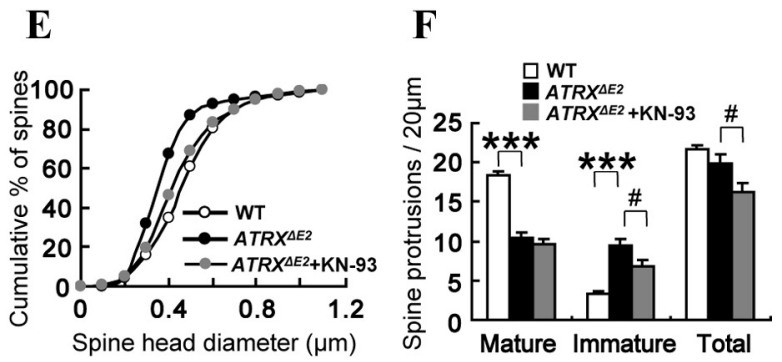

Figure 8. $\quad \boldsymbol{A}, \boldsymbol{B}$, Increased phosphorylation of Rac1-GEFs with okadaic acid is inhibited by KN-93 in cultured cortical neurons. $\boldsymbol{A}$, Representative immunoblots probed with various antibodies are shown in total lysate from mPFC. $B$, Quantitative densitometry analyses are shown. Data are expressed as percentage of value of wild-type mice. Each bar represents the mean \pm SEM. ${ }^{*} p<0.05$, ${ }^{* *} p<0.01$ in control versus okadaic acid; $\# p<0.05$, \#\#p $<0.01$ in okadaic acid versus okadaic acid plus KN-93; $n=5$ in each group. $C-F, K N-93$ infusion into $A T R X^{\Delta E 2}$ mouse $m P F C$ partly reversed the abnormal spine morphological changes observed in $A T R X^{\Delta E 2}$ mice. $\boldsymbol{C}$, Morphology of apical dendrites in wild-type mice, ATRX ${ }^{\Delta E 2}$ mice, and KN-93-treated ATRX ${ }^{\Delta E 2}$ mice. $\boldsymbol{D}-\boldsymbol{F}$, Quantitative analysis of apical spine morphology in wild-type mice (white circles and white bars), ATRX ${ }^{\Delta E 2}$ mice (black circles and black bars), and KN-93 treated $A T R X^{\Delta E 2}$ mice (gray circles and gray bars). $\boldsymbol{D}, \boldsymbol{E}$, Cumulative distribution of spine neck length $(\boldsymbol{D})$ and spine head diameter $(\boldsymbol{E})$. $\boldsymbol{F}$, Spine protrusions per $20 \mu \mathrm{m}$ dendritic length. Each bar represents the mean $\pm \mathrm{SEM}$. ${ }^{* * *} p<0.001$ in WT versuS $A T R X^{\Delta E 2}$. \#p $<0.05$ in $A T R X^{\Delta E 2}$ versus KN-93 treated $A T R X^{\Delta E 2}$. Scale bar, $2 \mu \mathrm{m}$. WT, Wild-type mice; ATRX $^{\Delta E 2}$, ATRX $^{\Delta E 2}$ mice.

ATRX-null mutant mice, in which conditional deletion of $A T R X$ exon 18 promotes loss of cortical mass due to increased neuronal apoptosis during early stages of cortical development, rarely survive past the first 2 postnatal days (Bérubé et al., 2005). Thus, ATRX protein is essential for normal development and cortical organization of the brain. Since null ATRX mutations do not exist in humans, mutation creating premature stop codon results in low-level expression of full-length ATRX protein in humans (Gibbons et al., 2008). Analysis of the 5' end of the ATRX gene reveals that a truncated ATRX protein is transcribed from a downstream AUG start codon at residue 40 in exon 2 (Howard et al., 2004). We also identified splicing variants in which ATRX protein is translated from AUG start codon present in exon 1, 2, or 3 in wild-type mice (Nogami et al., 2010). Since ATRX gene is composed with 35 exons. The transcribed products from exons 1 , 2 , and 3 are indistinguishable on normal SDS-PAGE. Since exon 2 was deleted in $A T R X^{\Delta E 2}$ mice, ATRX protein is possibly translated from the downstream AUG codon in exon 3. Thus, the ATRX protein expressed in $A T R X^{\Delta E 2}$ mice has a molecular weight similar to those in wild-type mice, but its expression level is largely attenuated (Fig. $5 A, B$ ).

Four affected male cousins, who exhibit ATRX mutations in exon 2, reportedly show moderate mental retardation (Guerrini et al., 2000). Three males with Chudley-Lowry syndrome (Chudley et al., 1988) were also identified to harbor an R37X mutation in exon 2 of ATRX (Abidi et al., 2005). The relatively mild retardation phenotypes observed in patients with this mutation may be due to the reduced expression of ATRX protein (Howard et al., 2004). In $A T R X^{\Delta E 2}$ mice, changes in ATRX biochemical activity have not been evaluated. Although the function of shortened ATRX protein, which is translated from downstream AUG codons in exon 3 , remains unclear (Nogami et al., 2010), indicating $A T R X^{\Delta E 2}$ mice may be an animal model of ATR-X syndrome, including Chudley-Lowry syndrome.

Although the long, thin spines seen in the $A T R X^{\Delta E 2}$ mice may due to CaMKII activation, the mechanism underlying elevated CaMKII activity in these mice remains unclear. Reduced PP1 levels and activity likely account in part for increased CaMKII activity. CaMKII localized in the rat forebrain PSD fraction is predominantly dephosphorylated by PP1 (Strack et al., 1997). We previously showed in vitro that pyramidal cells injected with calyculin A, a PP1/PP2A inhibitor that markedly enhances autophosphorylation of endogenous CaMKII, exhibited filopodia and that new spines were observed in rat hippocampal slice culture (Jourdain et al., 2003), suggesting that decreased PP1/PP2A activity alters spine morphology. Spinophilin, an actin- and PP1binding protein, is also specifically enriched in dendritic spines where it functions as a scaffold protein for the AMPA receptor (Allen et al., 1997). Therefore, a spinophilin/PP1 complex likely plays a role in synapse structural organization by regulating spine morphology through controlling CaMKII activity in spines (Fig. 9). Neurons from mice lacking spinophilin exhibit disrupted spine formation, with more numerous and elongated spines (Feng et al., 2000). Disrupting the function of the cytoskeletal spinophilin/PP1 complex also enhanced filopodia formation in HEK293 and COS7 cells (Oliver et al., 2002) and in cultured hippocampal neurons (Terry-Lorenzo et al., 2005). Likewise, decreased PP1/PP2A activity in Angelman syndrome (AS) model mice correlates with increased phosphorylation of hippocampal CaMKII (Thr286) in PSD and with disruptions in synaptic plasticity, learning, and memory (Weeber et al., 2003). Thus, we sug- 
gest that increased CaMKII activity is in part mediated by reduced PP1 activity, particularly in the PSD fraction.

We also addressed activation of Rac1GEFs, including Tiam1 and kalirin-7, as downstream targets for elevated CaMKII activity in $A T R X^{\Delta E 2}$ mice. Tiam1 phosphorylation by CaMKII enhances its nucleotide exchange rate toward Rac1, and such phosphorylation is inhibited in Swiss 3T3 fibroblasts by PP1 treatment (Fleming et al., 1999). Tiam1 mediates activitydependent increases in spine density during synapse development and maturation in cultured hippocampal and cortical neurons (Tolias et al., 2005). Likewise, kalirin-7 phosphorylation by CaMKII mediates activity-dependent formation of dendrites and increased spine size in cultured rat cortical neurons (Xie et al., 2007). Together, Tiam 1 and kalirin-7 are potential targets for CaMKII to activate Rac1, thereby leading to aberrant spine formation in $A T R X^{\Delta E 2}$ mice.

Interestingly, following contextual fear conditioning, a CpG island in the PP1 gene is modified epigenetically in adult rat hippocampus. DNA methyltransferase gene expression is upregulated and associated with rapid methylation and transcriptional silencing of PP1 during memory consolidation (Miller and Sweatt, 2007). In ATR-X patients, ATRX mutations give rise to changes in methylation patterns of several highly repeated sequences (Gibbons et al., 2000). We hypothesize that alterations in DNA methylation patterns play a role in mental retardation including ATR-X syndrome, and that decreases in PP1 protein expression result from hypermethylation of a PP1 $\mathrm{CpG}$ island and consequent gene silencing. Interestingly, PP1 mRNA levels were significantly decreased in $\mathrm{MPFC}$ but not in hippocampus of $A T R X^{\Delta E 2}$ mice. Thus, increased CaMKII activity seen in the mPFC of $A T R X^{\Delta E 2}$ mice could be due to decreased PP1 expression by hypermethylation of a PP1 CpG island. Further extensive studies are required to define this type of gene regulatory activity in $A T R X^{\Delta E 2}$ mice. In contrast to elevated CaMKII activity seen in the $\mathrm{mPFC}$, we previously reported reduced CaMKII activity in the hippocampus of $A T R X^{\Delta E 2}$ mice. Further analysis of epigenetic modifications should be performed to explain paradoxical CaMKII activity in $\mathrm{MPFC}$ and hippocampus of $A T R X^{\Delta E 2}$ mice.

Like ATR-X syndrome, Rett syndrome is an X-linked neurological condition marked by mental retardation in females and caused by mutations in the methyl-CpG-binding protein 2 (MeCP2) gene (Amir et al., 1999). MeCP2 phosphorylation at Ser421 by CaMKII is required for MeCP2-dependent regulation of dendritic patterning and spine morphogenesis through activity-dependent induction of brain-derived neurotrophic factor (Zhou et al., 2006). Notably, MeCP2 can recruit the helicase domain of ATRX to heterochromatic foci in living mouse cells in a DNA methylation-dependent manner (Nan et al., 2007). AS is also a genetic disorder characterized by movement disorders, sei-

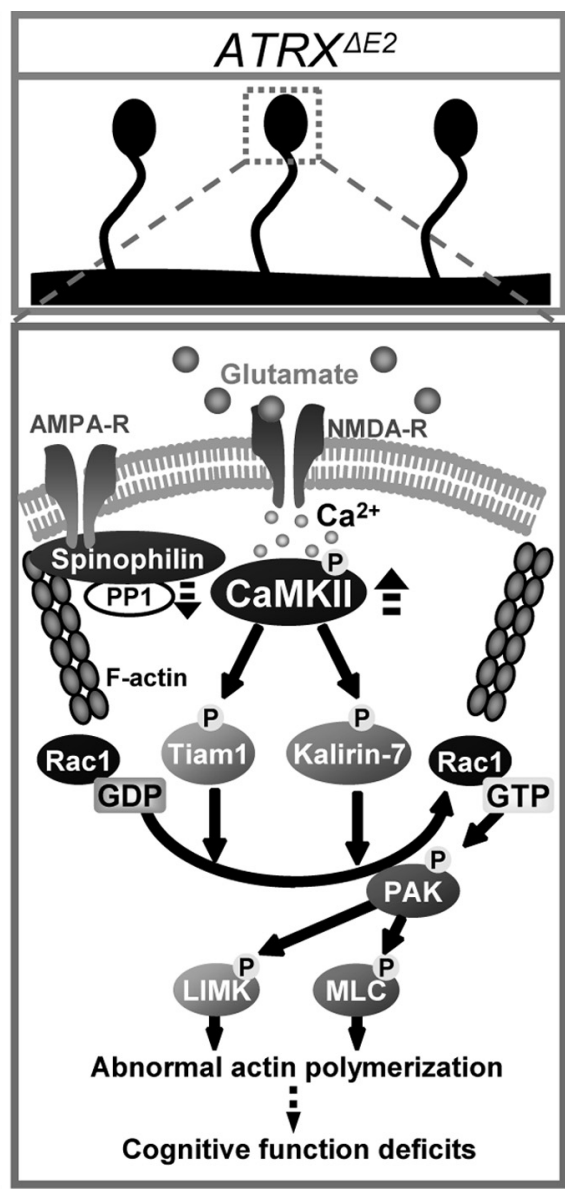

Cognitive function deficits

Figure 9. Schematic representation of altered spine morphology and mechanisms underlying this effect in ATRX ${ }^{\Delta E 2}$ mice.

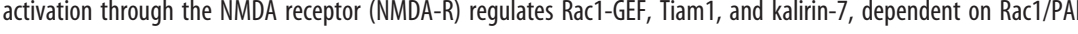
activation. PP1 inhibits CaMKIl activity by dephosphorylation. The ATRX mutation promotes losses in the spinophilin/PP1 complex, thereby promoting CaMKII cascades abnormally. Activation of CaMKII regulates GEF-dependent Rac1 activation. Finally, GTPbound Rac1 activates PAKs, altering spine formation. AMPA-R, AMPA receptor.

zures, and mental retardation (Williams et al., 1995; Buoni et al., 1999; Laan et al., 1999). AS model mice show decreased CaMKII activity with concomitant decreases in density and length of dendritic spines in hippocampal and cortical pyramidal neurons (Weeber et al., 2003; Dindot et al., 2008). When AS model mice were crossed with mouse mutants expressing an activated form of CaMKII, which lacks an inhibitory phosphorylation site at Thr305/306, reduced CaMKII activity was restored and phenotypes seen in AS model mice such as seizure and deficits of longterm potentiation, spatial learning, and fear conditioning (van Woerden et al., 2007) were rescued. Together, dysregulation of CaMKII may be common to cognitive deficits and aberrant spine morphology observed both in AS and ATR-X model mice. Further studies are required to define the mechanisms underlying dysregulated CaMKII activity in these animal models of mental retardation.

In conclusion, we have documented that CaMKII dysregulation potentially underlies aberrant spine formation in $A T R X^{\Delta E 2}$ mice. Phosphorylation of Rac1-GEFs including Tiam 1 and kalirin-7 by CaMKII likely mediates aberrant spine formation through PAK activation. However, the precise mechanism of aberrant activation of CaMKII remains unclear. Since PP1 plays a prominent role in regulating CaMKII autophosphorylation in postsynaptic densities (Strack et al., 1997), our observation of reduced PP1 expression is a key observa- 
tion to resolve this question. We are now analyzing mRNA expression and profiling the methylation state of CpG islands in genes including PP1 and its associated protein spinophilin in $A T R X^{\Delta E 2}$ mice.

\section{References}

Abidi FE, Cardoso C, Lossi AM, Lowry RB, Depetris D, Mattéi MG, Lubs HA, Stevenson RE, Fontes M, Chudley AE, Schwartz CE (2005) Mutation in the $5^{\prime}$ alternatively spliced region of the XNP/ATR-X gene causes Chudley-Lowry syndrome. Eur J Hum Genet 13:176-183.

Abidi F, Schwartz CE, Carpenter NJ, Villard L, Fontés M, Curtis M (1999) Carpenter-Waziri syndrome results from a mutation in XNP. Am J Med Genet 85:249-251

Allen PB, Ouimet CC, Greengard P (1997) Spinophilin, a novel protein phosphatase 1 binding protein localized to dendritic spines. Proc Natl Acad Sci U S A 94:9956-9961.

Amir RE, Van den Veyver IB, Wan M, Tran CQ, Francke U, Zoghbi HY (1999) Rett syndrome is caused by mutations in X-linked MECP2, encoding methyl-CpG-binding protein 2. Nat Genet 23:185-188.

Bérubé NG, Mangelsdorf M, Jagla M, Vanderluit J, Garrick D, Gibbons RJ, Higgs DR, Slack RS, Picketts DJ (2005) The chromatin-remodeling protein ATRX is critical for neuronal survival during corticogenesis. J Clin Invest 115:258-267.

Bokoch GM (2003) Biology of the p21-activated kinases. Annu Rev Biochem 72:743-781.

Brown MW, Aggleton JP (2001) Recognition memory: what are the roles of the perirhinal cortex and hippocampus? Nat Rev Neurosci 2:51-61.

Buoni S, Grosso S, Pucci L, Fois A (1999) Diagnosis of Angelman syndrome: clinical and EEG criteria. Brain Dev 21:296-302.

Chang YM, Rosene DL, Killiany RJ, Mangiamele LA, Luebke JI (2005) Increased action potential firing rates of layer $2 / 3$ pyramidal cells in the prefrontal cortex are significantly related to cognitive performance in aged monkeys. Cereb Cortex 15:409-418.

Chudley AE, Lowry RB, Hoar DI (1988) Mental retardation, distinct facial changes, short stature, obesity, and hypogonadism: a new X-linked mental retardation syndrome. Am J Med Genet 31:741-751.

Crawley J, Goodwin FK (1981) Preliminary report of a simple animal behavior model for the anxiolytic effects of benzodiazepines. Pharmacol Biochem Behav 13:167-170.

Dindot SV, Antalffy BA, Bhattacharjee MB, Beaudet AL (2008) The Angelman syndrome ubiquitin ligase localizes to the synapse and nucleus, and maternal deficiency results in abnormal dendritic spine morphology. Hum Mol Genet 17:111-118.

Feng J, Yan Z, Ferreira A, Tomizawa K, Liauw JA, Zhuo M, Allen PB, Ouimet CC, Greengard P (2000) Spinophilin regulates the formation and function of dendritic spines. Proc Natl Acad Sci U S A 97:9287-9292.

Fichera M, Romano C, Castiglia L, Failla P, Ruberto C, Amata S, Greco D, Cardoso C, Fonte's M, Ragusa A (1998) New mutations in XNP/ATR-X gene: a further contribution to genotype/phenotype relationship in ATR-X syndrome. Hum Mut 12:214.

Fink CC, Bayer KU, Myers JW, Ferrell JE Jr, Schulman H, Meyer T (2003) Selective regulation of neurite extension and synapse formation by the beta but not the alpha isoform of CaMKII. Neuron 39:283-297.

Fleming IN, Elliott CM, Buchanan FG, Downes CP, Exton JH (1999) Ca2+/ calmodulin-dependent protein kinase II regulates Tiam1 by reversible protein phosphorylation. J Biol Chem 274:12753-12758.

Frankland PW, Bontempi B (2005) The organization of recent and remote memories. Nat Rev Neurosci 6:119-130.

Fukunaga K, Goto S, Miyamoto E (1988) Immunohistochemical localization of $\mathrm{Ca}^{2+} /$ calmodulin-dependent protein kinase II in rat brain and various tissues. J Neurochem 51:1070-1078.

Fukunaga K, Rich DP, Soderling TR (1989) Generation of the Ca2(+)independent form of $\mathrm{Ca} 2+/$ calmodulin-dependent protein kinase II in cerebellar granule cells. J Biol Chem 264:21830-21836.

Fukunaga K, Soderling TR, Miyamoto E (1992) Activation of Ca2+/ calmodulin-dependent protein kinase II and protein kinase $\mathrm{C}$ by glutamate in cultured rat hippocampal neurons. J Biol Chem 267:22527-22533.

Fukunaga K, Kobayashi T, Tamura S, Miyamoto E (1993) Dephosphorylation of autophosphorylated $\mathrm{Ca}^{2+} /$ calmodulin-dependent protein kinase II by protein phosphatase 2C. J Biol Chem 268:133-137.

Fukunaga K, Muller D, Ohmitsu M, Bakó E, DePaoli-Roach AA, Miyamoto E
(2000) Decreased protein phosphatase 2A activity in hippocampal longterm potentiation. J Neurochem 74:807-817.

Gibbons RJ, Brueton L, Buckle VJ, Burn J, Clayton-Smith J, Davison BC, Gardner RJ, Homfray T, Kearney L, Kingston HM, Newbury-Ecob R, Porteous MEP, Wilkie AOM, Higgs DR (1995a) Clinical and hematological aspects of the X-linked a-thalassemia/mental retardation syndrome (ATR-X). Am J Med Genet 55:288-299.

Gibbons RJ, Picketts DJ, Villard L, Higgs DR (1995b) Mutations in a putative global transcriptional regulator cause X-linked mental retardation with thalassemia (ATR-X syndrome). Cell 80:837-845.

Gibbons RJ, Bachoo S, Picketts DJ, Aftimos S, Asenbauer B, Bergoffen J, Berry SA, Dahl N, Fryer A, Keppler K, Kurosawa K, Levin ML, Masuno M, Neri G, Pierpont ME, Slaney SF, Higgs DR (1997) Mutations in transcriptional regulator ATRX establish the functional significance of a PHD-like domain. Nat Genet 17:146-148.

Gibbons RJ, McDowell TL, Raman S, O’Rourke DM, Garrick D, Ayyub H, Higgs DR (2000) Mutations in ATRX, encoding a SWI/SNF-like protein, cause diverse changes in the pattern of DNA methylation. Nat Genet 24:368-371.

Gibbons RJ, Wada T, Fisher CA, Malik N, Mitson MJ, Steensma DP, Fryer A, Goudie DR, Krantz ID, Traeger-Synodinos J (2008) Mutations in the chromatin-associated protein ATRX. Hum Mutat 29:796-802.

Guerrini R, Shanahan JL, Carrozzo R, Bonanni P, Higgs DR, Gibbons RJ (2000) A nonsense mutation of the ATRX gene causing mild mental retardation and epilepsy. Ann Neurol 47:117-121.

Han F, Shioda N, Moriguchi S, Qin ZH, Fukunaga K (2008) The vanadium (IV) compound rescues septo-hippocampal cholinergic neurons from neurodegeneration in olfactory bulbectomized mice. Neuroscience 151:671-679.

Han F, Nakano T, Yamamoto Y, Shioda N, Lu YM, Fukunaga K (2009) Improvement of depressive behaviors by nefiracetam is associated with activation of CaM kinases in olfactory bulbectomized mice. Brain Res 1265:205-214.

Howard MT, Malik N, Anderson CB, Voskuil JL, Atkins JF, Gibbons RJ (2004) Attenuation of an amino-terminal premature stop codon mutation in the ATRX gene by an alternative mode of translational initiation. J Med Genet 41:951-956.

Irwin SA, Idupulapati M, Gilbert ME, Harris JB, Chakravarti AB, Rogers EJ, Crisostomo RA, Larsen BP, Mehta A, Alcantara CJ, Patel B, Swain RA, Weiler IJ, Oostra BA, Greenough WT (2002) Dendritic spine and dendritic field characteristics of layer $\mathrm{V}$ pyramidal neurons in the visual cortex of fragile-X knockout mice. Am J Med Genet 111:140-146.

Jourdain P, Fukunaga K, Muller D (2003) Calcium/calmodulin-dependent protein kinase II contributes to activity-dependent filopodia growth and spine formation. J Neurosci 23:10645-10649.

Kasahara J, Fukunaga K, Miyamoto E (1999) Differential effects of a calcineurin inhibitor of glutamate-induced phosphorylation of $\mathrm{Ca}^{2+} /$ calmodulin-dependent protein kinases in cultured rat hippocampal neurons. J Biol Chem 274:9061-9067.

Kaufmann WE, Moser HW (2000) Dendritic anomalies in disorders associated with mental retardation. Cereb Cortex 10:981-991.

Kennedy MB (2000) Signal-processing machines at the postsynaptic density. Science 290:750-754.

Laan LA, v Haeringen A, Brouwer OF (1999) Angelman syndrome: a review of clinical and genetic aspects. Clin Neurol Neurosurg 101:161-170.

Lai Y, Nairn AC, Greengard P (1986) Autophosphorylation reversibly regulates the $\mathrm{Ca} 2+/$ calmodulin dependence of $\mathrm{Ca} 2+/$ calmodulindependent protein kinase II. Proc Natl Acad Sci U S A 83:4253-4257.

Lei M, Lu W, Meng W, Parrini MC, Eck MJ, Mayer BJ, Harrison SC (2000) Structure of PAK1 in an autoinhibited conformation reveals a multistage activation switch. Cell 102:387-397.

Lossi AM, Millán JM, Villard L, Orellana C, Cardoso C, Prieto F, Fontés M Martínez F (1999) Mutation of the XNP/ATR-X gene in a family with severe mental retardation, spastic paraplegia and skewed pattern of $X$ inactivation: demonstration that the mutation is involved in the inactivation bias. Am J Hum Genet 65:558-562.

Manser E, Chong C, Zhao ZS, Leung T, Michael G, Hall C, Lim L (1995) Molecular cloning of a new member of the p21-Cdc42/Rac-activated kinase (PAK) family. J Biol Chem 270:25070-25078.

McDowell TL, Gibbons RJ, Sutherland H, O’Rourke DM, Bickmore WA Pombo A, Turley H, Gatter K, Picketts DJ, Buckle VJ, Chapman L, Rhodes D, Higgs DR (1999) Localization of a putative transcriptional regulator 
(ATRX) at pericentromeric heterochromatin and the short arms of acrocentric chromosomes. Proc Natl Acad Sci U S A 96:13983-13988.

Merrill MA, Chen Y, Strack S, Hell JW (2005) Activity-driven postsynaptic translocation of CaMKII. Trends Pharmacol Sci 26:645-653.

Miller CA, Sweatt JD (2007) Covalent modification of DNA regulates memory formation. Neuron 53:857-869.

Morgan MA, Romanski LM, LeDoux JE (1993) Extinction of emotional learning: contribution of medial prefrontal cortex. Neurosci Lett 163:109-113.

Murakawa R, Kosaka T (2001) Structural features of mossy cells in the hamster dentate gyrus, with special reference to somatic thorny excrescences. J Comp Neurol 429:113-126.

Nan X, Hou J, Maclean A, Nasir J, Lafuente MJ, Shu X, Kriaucionis S, Bird A (2007) Interaction between chromatin proteins MECP2 and ATRX is disrupted by mutations that cause inherited mental retardation. Proc Natl Acad Sci U S A 104:2709-2714.

Nogami T, Beppu H, Tokoro T, Moriguchi S, Shioda N, Fukunaga K, Ohtsuka T, Yoko I, Sasahara M, Shimada Y, Nishijo H, Li E, Kitajima I (2010) Reduced expression of the ATRX gene, a chromatin-remodeling factor, causes hippocampal dysfunction in mice. Hippocampus. Advance online publication. Retrieved November 24, 2010. doi:10.1002/hipo.20782.

Okamoto K, Nagai T, Miyawaki A, Hayashi Y (2004) Rapid and persistent modulation of actin dynamics regulates postsynaptic reorganization underlying bidirectional plasticity. Nat Neurosci 7:1104-1112.

Oliver CJ, Terry-Lorenzo RT, Elliott E, Bloomer WA, Li S, Brautigan DL, Colbran RJ, Shenolikar S (2002) Targeting protein phosphatase 1 (PP1) to the actin cytoskeleton: the neurabin I/PP1 complex regulates cell morphology. Mol Cell Biol 22:4690-4701.

Ouimet CC, da Cruz e Silva EF, Greengard P (1995) The alpha and gamma 1 isoforms of protein phosphatase 1 are highly and specifically concentrated in dendritic spines. Proc Natl Acad Sci U S A 92:3396-3400.

Patil SS, Sunyer B, Höger H, Lubec G (2009) Evaluation of spatial memory of $\mathrm{C} 57 \mathrm{BL} / 6 \mathrm{~J}$ and $\mathrm{CD} 1$ mice in the Barnes maze, the multiple T-maze and in the Morris water maze. Behav Brain Res 198:58-68.

Paxinos G, Franklin KBJ (2001) The mouse brain in stereotaxic coordinates. San Diego: Academic.

Pellow S, Chopin P, File SE, Briley M (1985) Validation of open:closed arm entries in an elevated plus-maze as a measure of anxiety in the rat. J Neurosci Methods 14:149-167.

Picketts DJ, Higgs DR, Bachoo S, Blake DJ, Quarrell OW, Gibbons RJ (1996) ATRX encodes a novel member of the SNF2 family of proteins: mutations point a common mechanism underlying the ATR-X syndrome. Hum Mol Genet 5:1899-1907.

Purpura DP (1974) Dendritic spine "dysgenesis" and mental retardation. Science 186:1126-1128.

Ramos E, Wysolmerski RB, Masaracchia RA (1997) Myosin phosphorylation by human cdc42-dependent S6/H4 kinase/gammaPAK from placenta and lymphoid cells. Recept Signal Transduct 7:99-110.

Robison AJ, Bass MA, Jiao Y, MacMillan LB, Carmody LC, Bartlett RK, Colbran RJ (2005) Multivalent interactions of calcium/calmodulindependent protein kinase II with the postsynaptic density proteins NR2B, densin-180, and alpha-actinin-2. J Biol Chem 280:35329-35336.

Schwartz ML, Goldman-Rakic PS (1984) Callosal and intrahemispheric connectivity of the prefrontal association cortex in rhesus monkey: relation between intraparietal and principal sulcal cortex. J Comp Neurol 226:403-420.

Schworer CM, Colbran RJ, Soderling TR (1986) Reversible generation of a $\mathrm{Ca} 2+$-independent form of $\mathrm{Ca} 2+$ (calmodulin)-dependent protein kinase II by an autophosphorylation mechanism. J Biol Chem 261:8581-8584.

Shen K, Meyer T (1999) Dynamic control of CaMKII translocation and localization in hippocampal neurons by NMDA receptor stimulation. Science 284:162-166.

Shen K, Teruel MN, Subramanian K, Meyer T (1998) CaMKIIbeta functions as an F-actin targeting module that localizes CaMKIIalpha/beta heterooligomers to dendritic spines. Neuron 21:593-606.

Shioda N, Moriguchi S, Shirasaki Y, Fukunaga K (2006) Generation of con- stitutively active calcineurin by calpain contributes to delayed neuronal death following mouse brain ischemia. J Neurochem 98:310-320.

Shioda N, Yamamoto Y, Watanabe M, Binas B, Owada Y, Fukunaga K (2010a) Heart-type fatty acid binding protein regulates dopamine D2 receptor function in mouse brain. J Neurosci 30:3146-3155.

Shioda N, Yamamoto Y, Han F, Moriguchi S, Yamaguchi Y, Hino M, Fukunaga K (2010b) A novel cognitive enhancer, ZSET1446/ST101, promotes hippocampal neurogenesis and ameliorates depressive behavior in olfactory bulbectomized mice. J Pharmacol Exp Ther 333:43-50.

Strack S, Barban MA, Wadzinski BE, Colbran RJ (1997) Differential inactivation of postsynaptic density-associated and soluble $\mathrm{Ca} 2+/$ calmodulindependent protein kinase II by protein phosphatases 1 and 2A. J Neurochem 68:2119-2128.

Takeuchi Y, Fukunaga K (2003) Differential subcellular localization of two dopamine D2 receptor isoforms in transfected NG108-15 cells. J Neurochem 85:1064-1074.

Terry-Lorenzo RT, Roadcap DW, Otsuka T, Blanpied TA, Zamorano PL, Garner CC, Shenolikar S, Ehlers MD (2005) Neurabin/protein phosphatase-1 complex regulates dendritic spine morphogenesis and maturation. Mol Biol Cell 16:2349-2362.

Tolias KF, Bikoff JB, Burette A, Paradis S, Harrar D, Tavazoie S, Weinberg RJ, Greenberg ME (2005) The Racl-GEF Tiam1 couples the NMDA receptor to the activity-dependent development of dendritic arbors and spines. Neuron 45:525-538.

van Woerden GM, Harris KD, Hojjati MR, Gustin RM, Qiu S, de Avila Freire R, Jiang YH, Elgersma Y, Weeber EJ (2007) Rescue of neurological deficits in a mouse model for Angelman syndrome by reduction of alphaCaMKII inhibitory phosphorylation. Nat Neurosci 10:280-282.

Villard L, Gecz J, Mattéi JF, Fontés M, Saugier-Veber P, Munnich A, Lyonnet S (1996a) XNP mutation in a large family with Juberg-Marsidi syndrome. Nat Genet 12:359-360.

Villard L, Toutain A, Lossi AM, Gecz J, Houdayer C, Moraine C, Fontès M (1996b) Splicing mutation in the ATR-X gene lead to a dysmorphic mental retardation phenotype without alpha-thalassemia. Am J Hum Genet 58:499-505.

Villard L, Lacombe D, Fontés M (1996c) A point mutation in the XNP gene, associated with an ATR-X phenotype without alpha-thalassemia. Eur J Hum Genet 4:316-320.

Villard L, Bonino MC, Abidi F, Ragusa A, Belougne J, Lossi AM, Seaver L, Bonnefont JP, Romano C, Fichera M, Lacombe D, Hanauer A, Philip N, Schwartz C, Fontés M (1999) Evaluation of a mutation screening strategy for sporadic cases of ATR-X syndrome. J Med Genet 36:183-186.

Weeber EJ, Jiang YH, Elgersma Y, Varga AW, Carrasquillo Y, Brown SE, Christian JM, Mirnikjoo B, Silva A, Beaudet AL, Sweatt JD (2003) Derangements of hippocampal calcium/calmodulin-dependent protein kinase II in a mouse model for Angelman mental retardation syndrome. J Neurosci 23:2634-2644.

Wilkie AO, Pembrey ME, Gibbons RJ, Higgs DR, Porteous ME, Burn J, Winter RM (1991) The non-deletion type of alpha thalassaemia/mental retardation: a recognizable dysmorphic syndrome with $\mathrm{X}$ linked inheritance. J Med Genet 28:724.

Williams CA, Angelman H, Clayton-Smith J, Driscoll DJ, Hendrickson JE, Knoll JH, Magenis RE, Schinzel A, Wagstaff J, Whidden EM (1995) Angelman syndrome: consensus for diagnostic criteria. Angelman Syndrome Foundation. Am J Med Genet 56:237-238.

Xie Z, Srivastava DP, Photowala H, Kai L, Cahill ME, Woolfrey KM, Shum CY, Surmeier DJ, Penzes P (2007) Kalirin-7 controls activity-dependent structural and functional plasticity of dendritic spines. Neuron 56: 640-656.

Zhou Z, Hong EJ, Cohen S, Zhao WN, Ho HY, Schmidt L, Chen WG, Lin Y, Savner E, Griffith EC, Hu L, Steen JA, Weitz CJ, Greenberg ME (2006) Brain-specific phosphorylation of MeCP2 regulates activity-dependent Bdnf transcription, dendritic growth, and spine maturation. Neuron 52: 255-269. 